\title{
Supergrupo Minas na Serra de Bom Sucesso, extremo sudoeste do Quadrilátero Ferrífero - MG: petrografia, geoquímica e isótopos de U-Pb Minas Supergroup in Serra de Bom Sucesso, extreme southwest of the Quadrilátero Ferrífero - MG: petrography, geochemistry and $U$-Pb isotope
}

\author{
Marcos Eduardo Nilton Vieira Neri ${ }^{1}$, Carlos Alberto Rosière ${ }^{1}$, Cristiano de Carvalho Lana ${ }^{2}$ \\ ${ }^{1}$ Instituto de Geociências, Universidade Federal de Minas Gerais - UFMG, Avenida Antônio Carlos 6.627, Campus Pampulha, \\ CEP 31270-901, Belo Horizonte, MG, BR (vieiraneri@yahoo.com.br; crosiere@gmail.com) \\ ${ }^{2}$ Departamento de Geologia, Escola de Minas, Universidade Federal de Ouro Preto - UFOP, Campus Morro do Cruzeiro, \\ Ouro Preto, MG, BR (cristianodeclana@gmail.com)
}

Recebido em 04 de julho de 2012; aceito em 10 de abril de 2013

\begin{abstract}
Resumo
No extremo sudoeste do Quadrilátero Ferrífero, porção sul do Cinturão Mineiro, está exposta uma faixa de metassedimentos que contém formações ferríferas bandadas, denominada, neste estudo, como Sequência Metassedimentar Bom Sucesso. A sequência tem empilhamento estratigráfico normal e é subdividida em três unidades, da base para o topo: xisto carbonático Lagoa da Prata, Formação Ferrífera Bandada Bom Sucesso e xisto Tabuãozinho. Dados U-Pb de zircão detrítico, de amostras da Unidade Lagoa da Prata, indicam idade máxima de deposição de $2603 \pm$ 7,3 Ma, correlacionando essa unidade com a base do Supergrupo Minas, o Grupo Caraça. A formação ferrífera bandada é predominantemente anfibolítica e possui intercalação de dolomitos ferruginosos descontínuos, apresentando contato transicional com xisto ferruginoso no topo da unidade. A formação ferrífera bandada contém anomalias positivas de Eu, Y e La, enriquecimento relativo de Elementos Terras Raras (ETR) pesados e ausência de anomalia negativa de Ce, análoga aos Itabiritos da Formação Cauê, Grupo Itabira. A Sequência Metassedimentar Bom Sucesso sofreu metamorfismo de contato associado a metassomatismo alcalino, gerado pela intrusão do Granito Tabuões, durante a orogenia Transamazônica.
\end{abstract}

Palavras-chave: Quadrilátero Ferrífero; Formação ferrífera bandada; Zircão; Supergrupo Minas; Bom Sucesso; ETR.

\begin{abstract}
The banded iron formation (BIF) hosted Bom Sucesso Metassedimentary Sequence (BSMS) is exposed in the southwest part of the Quadrilátero Ferrífero, Minas Gerais. This sequence has normal stratigraphic stacking and comprises three units: the lower Lagoa da Prata carbonate schist, the intermediate Bom Sucesso BIF and the upper Tabuãozinho schist. U-Pb detrital zircon data from samples of the Lagoa da Prata unit indicate a maximum age of deposition of $2603 \pm 7.3 \mathrm{Ma}$, correlated with the basal Caraça Group of the Minas Supergroup. The Bom Sucesso BIF has predominant mineralogy formed by bands of iron oxide (maghemite) and amphibole; it is interlayered with discontinuous ferruginous dolomite lenses and it grades upwards to a ferruginous metapelitic layer at the top of the unit. The geochemical signature of the BIF is characterized by positive anomalies of Eu, $\mathrm{Y}$ and La, relative enrichment of heavy Rare Earth Elements (REE) and absence of a negative Ce anomaly, analogous to the itabirites of the Itabira Group. The mineral assemblage of the BSMS indicates contact metamorphism associated with alkaline metasomatism, generated by the intrusion of the Tabuões Granite during the Transamazonian orogeny.
\end{abstract}

Keywords: Quadrilátero Ferrífero; Banded iron formation; Zircon; Minas Supergrup; Bom Sucesso; REE. 


\section{INTRODUÇÃO}

No extremo sudoeste do Quadrilátero Ferrífero, próximo à cidade de Bom Sucesso, MG, aflora uma sequência metassedimentar, em uma estreita faixa supracrustal, orientada na direção $\mathrm{N} 30^{\circ} \mathrm{E}$, com 500 a $1.000 \mathrm{~m}$ de largura e $30 \mathrm{~km}$ de extensão. Essa sequência é constituída por quartzito, xistos e formações ferríferas bandadas ricas em magnetita, que sofreram metamorfismo na fácies anfibolito. As formações ferríferas ocorrem nas variedades quartzosa, dolomítico-calcítica e anfibolítica e são cortadas por diques máficos e corpos pegmatíticos (Quéméneur et al., 2003).

Diversos trabalhos correlacionam esta sequência metassedimentar ao Supergrupo Minas (Machado Filho et al., 1983; Quéméneur et al., 2003; Chemale Jr. et al., 1992; Marshak et al., 1992), com base na concordância geral entre as estruturas do lineamento Jaceaba-Bom Sucesso. No entanto, a posição estratigráfica e o arcabouço estrutural desta sequência de rochas metassedimentares são bastante controversos, já que a região sofreu aparentemente o efeito de diversos eventos tectônicos associados a duas orogêneses desde o Paleo ao Neoproterozoico, além de estar posicionada próxima ao domínio de influência da Faixa Ribeira.

O presente estudo envolve a análise estrutural, petrológica, geoquímica e geocronológica por U-Pb da sequência metassedimentar da Serra de Bom Sucesso, localizada na cidade homônima, com ênfase no pacote de formação ferrífera bandada (FFB). O principal objetivo foi definir as características da sequência e da bacia de deposição, além de seu posicionamento temporal para correlacioná-la com outras sequências vizinhas. Com o intuito de caracterizar as variações da mineralogia dos óxidos de ferro, foram adicionalmente determinadas curvas termomagnéticas de modo a permitir a identificação da mineralogia magnética.

$\mathrm{O}$ mapeamento geológico de detalhe, em escala de 1:25.000, e a coleta de amostras de afloramentos e de furos de sondagem, para análise petrológica, geoquímica e isotópica se restringem a uma área aproximada de $140 \mathrm{~km}^{2} \mathrm{e}$ contêm a porção norte da Serra de Bom Sucesso, perfazendo $12 \mathrm{~km}$, lineares, na extensão da serra.

\section{GEOLOGIA REGIONAL}

No contexto geotectônico, a área de estudo situa-se no Cinturão Mineiro (Teixeira e Figueiredo, 1991), localizado na porção meridional do Cráton São Francisco (Almeida, 1977). A região é caracterizada como um segmento crustal siálico de evolução policíclica, tectonicamente estável em relação aos cinturões móveis do ciclo Brasiliano (Alkmim et al., 1993), tendo experimentado deformação (Alkmim e Marshak, 1998; Endo, 1997) e ação termal (Noce et al., 1998; Machado et al., 1992; Oliveira, 2004) durante o Paleoproterozoico. Desta forma, o cinturão engloba o Quadrilátero Ferrífero e os terrenos adjacentes a sudoeste, tem suas extensões nordeste e sudoeste fora do cráton, intensamente retrabalhadas durante o evento Brasiliano e constituintes do substrato das faixas Araçuaí e Brasília Sul, respectivamente (Alkmim, 2004).

O Supergrupo Minas está exposto no extremo norte do Cinturão Mineiro como uma sequência metassedimentar de idade paleoproterozoica (Machado et al., 1996; Babinski et al., 1991), interpretada por Chemale Jr. et al. (1994) como bacia intracratônica. É constituído, da base para o topo, por uma unidade dominantemente clástica (Grupo Caraça), unidade de rochas químicas, com carbonatos e formações ferríferas (Grupo Itabira), unidade de metassedimentos clásticos com rochas metassedimentares químicas subordinadas (Grupo Piracicaba) e por uma unidade interpretada como uma sequência do tipo flysch (Grupo Sabará; Renger et al., 1994; Alkmim e Marshak, 1998).

A faixa de metassedimentos que contém formações ferríferas bandadas, exposta no extremo sudoeste do Quadrilátero Ferrífero, sul do Cinturão Mineiro, estende-se paralelamente ao lineamento Jeceaba-Bom Sucesso e será denominada, neste estudo, como Sequência Metassedimentar Bom Sucesso. O lineamento JeceabaBom Sucesso tem direção geral NE-SW, desde a extremidade sul da Serra da Moeda, próximo à cidade de Jeceaba, até a cidade de Lavras (Figura 1) e, segundo Quéméneur et al. (2003), divide a região em dois blocos distintos. No bloco oeste, afloram unidades arqueanas, constituída por gnaisses, granitoides, anfibolitos, rochas máficas e ultramáficas, xistos e quartzitos (Machado Filho et al., 1983). O Bloco leste é caracterizado pela associação de faixas alongadas de rochas vulcanossedimentares do tipo greenstone belt (Greenstone Belt Rio das Mortes, Nazareno e Dores do Campo) intrudidas por plútons graníticos e tonalíticos paleoproterozoicos, associados aos estágios pré-, sin- e pós-tectônicos do Cinturão Mineiro (Noce et al., 2000; Teixeira et al., 2000).

\section{AMOSTRAGEM E MÉTODOS ANALÍTICOS}

\section{Geoquímica}

Foram selecionadas 11 amostras, sendo 9 de FFB e 2 de xisto ferruginoso. As amostras são provenientes de furos de sondagem e foram analisadas pelo método Inductively Coupled Plasma Optical Emission Spectrometry (ICP-OES), realizado por ACME Analytical Laboratories.

Os Elementos Terras Raras (ETR) foram normalizados aos padrões Post-Archean average Australian Shale PAAS $_{(\mathrm{SN})}-$ McLennan, 1989) e condritos $_{(\mathrm{NC})}$ (Taylor e McLennan, 1985). O Y foi adicionado entre o Dy e o Ho, e a base de cálculo para as anomalias dos ETR + Y estão 
apresentados na Tabela 1. Os dados utilizados das análises de amostras da Serra de Bom Sucesso são apresentados na Tabela 2. Dados analíticos de Spier et al. (2007) e do Projeto Magnetititos (CNPq - Proc. No472602/2009-8) foram utilizados, a fim de compará-los com os resultados obtidos nas amostras analisadas da FFB da Serra de Bom Sucesso. Os dados analíticos de Spier et al. (2007), referentes ao filito sericítico da Formação Batatal, unidade basal ao Grupo Itabira, foram comparados com o litotipo do
Tabela 1. Base de cálculo para as anomalias de Ce, Eu e Pr.

\begin{tabular}{|c|c|}
\hline Razões & Base de cálculo \\
\hline $\mathrm{Ce} / \mathrm{Ce}^{\star}$ & $\mathrm{Ce}_{(\mathrm{SN})} /\left(0,5 \mathrm{La}_{(\mathrm{SN})}+0,5 \mathrm{Pr}_{(\mathrm{SN})}\right)$ \\
\hline $\mathrm{Eu} / \mathrm{Eu}^{*}$ & $\mathrm{Eu}_{(\mathrm{SN})} /\left(0,66 \mathrm{Sm}_{(\mathrm{SN})}+0,33 \mathrm{~Tb}_{(\mathrm{SN})}\right)$ \\
\hline $\mathrm{Pr} / \mathrm{Pr}^{\star}$ & $\operatorname{Pr}_{(S N)} /\left(0,5 \mathrm{Ce}_{(S N)}+0,5 \mathrm{Nd}_{(S N)}\right)$ \\
\hline $\mathrm{La} / \mathrm{La}^{*}$ & $(\mathrm{La} / 3 \mathrm{Pr}-2 \mathrm{Nd})_{\mathrm{SN}}$ \\
\hline $\mathrm{Nd} / \mathrm{Nd}^{*}$ & $\mathrm{Nd}_{(\mathrm{SN})} /\left(0,5 \mathrm{Pr}_{(\mathrm{SN})}+0,5 \mathrm{Sm}_{(\mathrm{SN})}\right)$ \\
\hline$Y / Y^{*}$ & $Y_{(S N)} /\left(0,5 \mathrm{Gd}_{(S N)}+0,5 \mathrm{Ho}_{(S N)}\right)$ \\
\hline
\end{tabular}

Fonte: Bau e Dulski (1996).

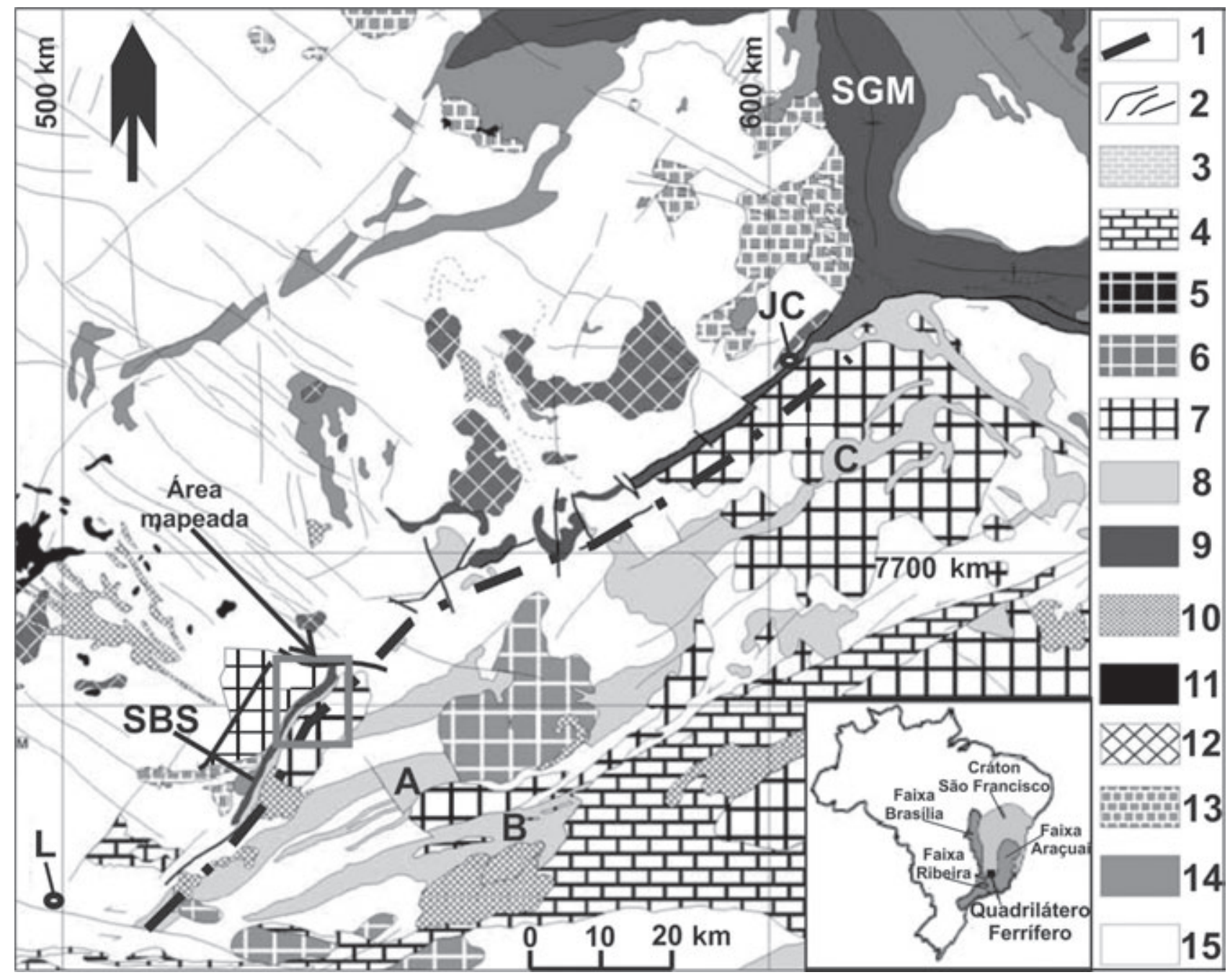

1: lineamento Jeceaba-Bom Sucesso; 2: lineamentos estruturais; 3: cobertura cratônica indivisa (Neoproterozoico); 4: unidades mesoproterozoicas indivisas; 5: granitos proterozoicos (<2,0 Ga); 6 e 7: plútons paleoproterozoicos (Suíte Ritápolis e Cassiterita-Tabuões, respectivamente); 8: sequência paleoproterozoica tipo Greenstone belt - A: Greenstone Belt Rio das Mortes; B: Greenstone Belt Nazareno; C: Greenstone Belt Dores do Campo; 9: sequências de metassedimentos com formação ferrífera bandada - SGM: Supergrupo Minas; SBS: Sequência Metassedimentar Bom Sucesso; 10: dioritos e gabros (diques e sills) neoarqueanos, paleoproterozoicos e mesoproterozoicos; 11: Complexo Charnokítico Babilônia; 12: Suíte Salto Paraopeba; 13: Suíte Bom Sucesso Samambaia; 14: Supergrupo Rio das Velhas (Neoarqueano); 15: unidades arqueanas indivisas; JC: Município de Jeceaba; L: Município de Lavras.

Figura 1. Mapa litológico da porção sul do Cinturão Mineiro, extremo sudoeste do Quadrilátero Ferrífero (compilado de Campos et al., 2003). 
Tabela 2. Concentração dos elementos maiores, traço e terras raras. Somatório da concentração absoluta (ppm) dos elementos

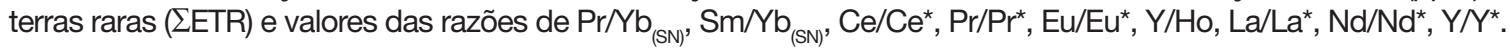

\begin{tabular}{|c|c|c|c|c|c|c|}
\hline Amostras & $\begin{array}{c}\text { BSA-019 } \\
\text { FFB }\end{array}$ & $\begin{array}{c}\text { BSA-001 } \\
\text { FFB }\end{array}$ & $\begin{array}{c}\text { BSA-011 } \\
\text { FFB }\end{array}$ & $\begin{array}{c}\text { BSA-018 } \\
\text { FFB }\end{array}$ & $\begin{array}{c}\text { BSA-006 } \\
\text { FFB }\end{array}$ & $\begin{array}{c}\text { BSA-010 } \\
\text { FFB }\end{array}$ \\
\hline \multicolumn{7}{|l|}{ wt\% } \\
\hline $\mathrm{Al}_{2} \mathrm{O}_{3}$ & 0,13 & 0,08 & 0,05 & 0,2 & 0,07 & 0,06 \\
\hline $\mathrm{CaO}^{2}$ & 5,81 & 2,5 & 2,5 & 3,58 & 2,41 & 5,25 \\
\hline $\mathrm{Cr}_{2} \mathrm{O}_{3}$ & $<0,002$ & $<0,002$ & $<0,002$ & $<0,002$ & 0,004 & $<0,002$ \\
\hline $\mathrm{Fe}_{2}^{2} \mathrm{O}_{3}$ & 45,71 & 50,48 & 49,48 & 44,63 & 48,16 & 46,11 \\
\hline $\mathrm{K}_{2} \mathrm{O}^{3}$ & 0,03 & 0,69 & 0,05 & 0,09 & 0,73 & 0,18 \\
\hline $\mathrm{MgO}^{2}$ & 3,05 & 2,76 & 3,59 & 5,59 & 2,68 & 6,21 \\
\hline $\mathrm{MnO}$ & 0,2 & 0,13 & 0,13 & 0,1 & 0,16 & 0,11 \\
\hline $\mathrm{Na}_{2} \mathrm{O}$ & 0,05 & 1,27 & 0,09 & 0,03 & 1,12 & 0,14 \\
\hline $\mathrm{P}_{2} \mathrm{O}_{5}$ & 0,08 & 0,03 & 0,1 & 0,15 & 0,09 & 0,16 \\
\hline $\mathrm{SiO}_{2}^{2}$ & 46,23 & 43,2 & 44,12 & 46,1 & 45,37 & 42,42 \\
\hline $\mathrm{TiO}_{2}^{2}$ & $<0,01$ & $<0,01$ & $<0,01$ & 0,01 & $<0,01$ & $<0,01$ \\
\hline TOT/C & 0,06 & $<0,02$ & $<0,02$ & 0,17 & 0,07 & $<0,02$ \\
\hline TOT/S & $<0,02$ & $<0,02$ & $<0,02$ & $<0,02$ & $<0,02$ & $<0,02$ \\
\hline LOI & $-1,4$ & $-1,2$ & $-0,2$ & $-0,6$ & $-0,9$ & $-0,8$ \\
\hline \multicolumn{7}{|l|}{ ppm } \\
\hline Au & 1,5 & 1 & $<0,5$ & $<0,5$ & 1,2 & 0,8 \\
\hline $\mathrm{Ba}$ & 8 & 18 & 6 & 10 & 23 & 14 \\
\hline $\mathrm{Be}$ & 1 & $<1$ & $<1$ & $<1$ & $<1$ & $<1$ \\
\hline $\mathrm{Ce}$ & 2,5 & 0,8 & 1,3 & 2,5 & 1,6 & 1,8 \\
\hline Co & 1 & 0,5 & 0,6 & 0,6 & 0,7 & 0,4 \\
\hline Cs & 0,6 & 0,9 & 0,1 & 2 & 0,7 & 1,8 \\
\hline Dy & 0,49 & 0,23 & 0,23 & 0,58 & 0,29 & 0,32 \\
\hline Er & 0,52 & 0,19 & 0,25 & 0,48 & 0,28 & 0,34 \\
\hline $\mathrm{Eu}$ & 0,13 & 0,04 & 0,07 & 0,12 & 0,07 & 0,06 \\
\hline $\mathrm{Ga}$ & 0,6 & $<0,5$ & 0,5 & 0,8 & 0,8 & $<0,5$ \\
\hline $\mathrm{Gd}$ & 0,43 & 0,18 & 0,18 & 0,5 & 0,25 & 0,25 \\
\hline $\mathrm{Hf}$ & $<0,1$ & $<0,1$ & $<0,1$ & 0,1 & $<0,1$ & $<0,1$ \\
\hline $\mathrm{Ho}$ & 0,14 & 0,05 & 0,07 & 0,16 & 0,09 & 0,1 \\
\hline La & 1,5 & 0,8 & 1,1 & 1,6 & 1,6 & 1,6 \\
\hline $\mathrm{Lu}$ & 0,09 & 0,04 & 0,04 & 0,09 & 0,05 & 0,06 \\
\hline $\mathrm{Nb}$ & 0,2 & 0,3 & 0,1 & 0,3 & 0,2 & 0,2 \\
\hline $\mathrm{Nd}$ & 1,5 & 0,5 & 0,6 & 1,5 & 0,8 & 0,9 \\
\hline $\mathrm{Ni}$ & $<20$ & $<20$ & $<20$ & $<20$ & $<20$ & $<20$ \\
\hline $\mathrm{Pr}$ & 0,31 & 0,11 & 0,14 & 0,32 & 0,19 & 0,21 \\
\hline $\mathrm{Rb}$ & 2,8 & 8,4 & 0,7 & 6,2 & 19,2 & 12,5 \\
\hline Sc & $<1$ & $<1$ & $<1$ & $<1$ & $<1$ & $<1$ \\
\hline $\mathrm{Sm}$ & 0,33 & 0,12 & 0,13 & 0,32 & 0,14 & 0,18 \\
\hline Sn & $<1$ & $<1$ & $<1$ & $<1$ & $<1$ & 6 \\
\hline $\mathrm{Sr}$ & 78,6 & 87,3 & 35,2 & 46,4 & 130,7 & 98,9 \\
\hline $\mathrm{Ta}$ & $<0,1$ & $<0,1$ & $<0,1$ & $<0,1$ & $<0,1$ & $<0,1$ \\
\hline $\mathrm{Tb}$ & 0,09 & 0,03 & 0,04 & 0,09 & 0,05 & 0,05 \\
\hline Th & $<0,2$ & $<0,2$ & $<0,2$ & 0,2 & $<0,2$ & $<0,2$ \\
\hline $\mathrm{Tm}$ & 0,08 & 0,03 & 0,03 & 0,09 & 0,05 & 0,06 \\
\hline U & $<0,1$ & $<0,1$ & $<0,1$ & $<0,1$ & $<0,1$ & $<0,1$ \\
\hline V & $<8$ & $<8$ & $<8$ & $<8$ & $<8$ & $<8$ \\
\hline W & $<0,5$ & $<0,5$ & $<0,5$ & $<0,5$ & $<0,5$ & $<0,5$ \\
\hline$Y$ & 6,1 & 2,4 & 3,5 & 6,9 & 4,2 & 5,1 \\
\hline $\mathrm{Yb}$ & 0,54 & 0,2 & 0,27 & 0,55 & 0,26 & 0,41 \\
\hline $\mathrm{Zr}$ & 2,5 & 1,8 & 0,8 & 3,2 & 1 & 1 \\
\hline Mo & 0,2 & 0,1 & 0,3 & 0,2 & 0,2 & 0,2 \\
\hline $\mathrm{Cu}$ & 1,4 & 0,7 & 1,8 & 1,4 & 1 & 1,2 \\
\hline $\mathrm{Pb}$ & 1,4 & 0,9 & 0,6 & 2,8 & 0,1 & 0,8 \\
\hline $\mathrm{Zn}$ & 8 & 2 & 3 & 4 & 5 & 4 \\
\hline $\mathrm{Ni}$ & 1,6 & 1 & 1,4 & 1,4 & 0,7 & 1,3 \\
\hline As & 1,2 & 0,8 & 3,6 & 1 & 1 & 2 \\
\hline $\mathrm{Cd}$ & $<0,1$ & $<0,1$ & $<0,1$ & $<0,1$ & $<0,1$ & $<0,1$ \\
\hline $\mathrm{Sb}$ & 0,1 & $<0,1$ & 0,4 & 0,4 & $<0,1$ & 0,1 \\
\hline $\mathrm{Ag}$ & $<0,1$ & $<0,1$ & $<0,1$ & $<0,1$ & $<0,1$ & $<0,1$ \\
\hline
\end{tabular}


Tabela 2. Continuação.

\begin{tabular}{|c|c|c|c|c|c|}
\hline \multirow{2}{*}{ Amostras } & BSA-013 & BSA-003 & BSA-020 & BSA-004 & BSA-024 \\
\hline & FFB & FFB & FFB & Xisto Ferruginoso & Xisto Ferruginoso \\
\hline \multicolumn{6}{|l|}{ wt\% } \\
\hline $\mathrm{Al}_{2} \mathrm{O}_{3}$ & 0,02 & 0,19 & 0,05 & 5,03 & 11 \\
\hline $\mathrm{CaO}^{3}$ & 0,36 & 6,04 & 3,41 & 3,86 & 2,8 \\
\hline $\mathrm{Cr}_{2} \mathrm{O}_{3}$ & $<0,002$ & $<0,002$ & $<0,002$ & 0,01 & 0,029 \\
\hline $\mathrm{Fe}_{2}^{2} \mathrm{O}_{3}^{3}$ & 47,24 & 45,19 & 49,48 & 30,43 & 20,44 \\
\hline $\mathrm{K}_{2} \mathrm{O}$ & 0,02 & 0,04 & 0,09 & 0,77 & 0,08 \\
\hline $\mathrm{MgO}$ & 5,59 & 3,46 & 2,59 & 2,95 & 9,39 \\
\hline $\mathrm{MnO}$ & 0,13 & 0,24 & 0,12 & 0,19 & 6,32 \\
\hline $\mathrm{Na}_{2} \mathrm{O}$ & 0,02 & 0,04 & 0,18 & 0,18 & 0,03 \\
\hline $\mathrm{P}_{2} \mathrm{O}_{5}$ & 0,06 & 0,1 & 0,11 & 0,08 & 0,11 \\
\hline $\mathrm{SiO}_{2}^{2}$ & 47,36 & 45,99 & 45,22 & 56,57 & 48,77 \\
\hline $\mathrm{TiO}_{2}^{2}$ & $<0,01$ & 0,01 & $<0,01$ & 0,18 & 0,51 \\
\hline TOT/C & $<0,02$ & 0,04 & $<0,02$ & 0,02 & 0,2 \\
\hline TOT/S & $<0,02$ & $<0,02$ & $<0,02$ & $<0,02$ & $<0,02$ \\
\hline LOI & $-0,9$ & $-1,4$ & $-1,3$ & $-0,4$ & 0,3 \\
\hline \multicolumn{6}{|l|}{ ppm } \\
\hline $\mathrm{Au}$ & 1 & 0,9 & 1 & 16,8 & 0,9 \\
\hline $\mathrm{Ba}$ & 6 & 9 & 5 & 92 & 10 \\
\hline $\mathrm{Be}$ & $<1$ & $<1$ & $<1$ & 1 & $<1$ \\
\hline $\mathrm{Ce}$ & 0,7 & 2,8 & 1,9 & 34,1 & 66,4 \\
\hline Co & 0,3 & 0,6 & 0,6 & 6,8 & 16,6 \\
\hline Cs & 0,4 & 1,4 & $<0,1$ & 3,6 & 1,4 \\
\hline Dy & 0,23 & 0,62 & 0,29 & 2,64 & 4,65 \\
\hline Er & 0,17 & 0,48 & 0,28 & 1,65 & 2,63 \\
\hline $\mathrm{Eu}$ & 0,04 & 0,11 & 0,05 & 0,49 & 1,11 \\
\hline $\mathrm{Ga}$ & 0,6 & 3,8 & 1,1 & 7 & 18,2 \\
\hline $\mathrm{Gd}$ & 0,13 & 0,43 & 0,24 & 2,5 & 4,7 \\
\hline $\mathrm{Hf}$ & $<0,1$ & $<0,1$ & $<0,1$ & 1,5 & 5,1 \\
\hline $\mathrm{Ho}$ & 0,05 & 0,14 & 0,08 & 0,54 & 0,9 \\
\hline La & 0,5 & 2,3 & 1,8 & 18,9 & 35,4 \\
\hline Lu & 0,04 & 0,08 & 0,05 & 0,25 & 0,37 \\
\hline $\mathrm{Nb}$ & 0,2 & 0,2 & 0,3 & 5,9 & 8,6 \\
\hline $\mathrm{Nd}$ & 0,7 & 1,4 & 1 & 13,2 & 27,8 \\
\hline $\mathrm{Ni}$ & $<20$ & $<20$ & $<20$ & 31 & 76 \\
\hline $\mathrm{Pr}$ & 0,08 & 0,34 & 0,2 & 3,86 & 7,47 \\
\hline $\mathrm{Rb}$ & 1,4 & 5,2 & 1,1 & 47,2 & 3,9 \\
\hline Sc & $<1$ & $<1$ & $<1$ & 5 & 11 \\
\hline $\mathrm{Sm}$ & 0,11 & 0,32 & 0,17 & 2,69 & 5,03 \\
\hline $\mathrm{Sn}$ & $<1$ & $<1$ & $<1$ & 3 & 3 \\
\hline $\mathrm{Sr}$ & 8,6 & 152,6 & 144,6 & 42 & 14,6 \\
\hline $\mathrm{Ta}$ & $<0,1$ & $<0,1$ & $<0,1$ & 0,6 & 1,2 \\
\hline $\mathrm{Tb}$ & 0,03 & 0,08 & 0,04 & 0,43 & 0,79 \\
\hline Th & $<0,2$ & 0,4 & $<0,2$ & 8,5 & 15,3 \\
\hline $\mathrm{Tm}$ & 0,03 & 0,07 & 0,04 & 0,26 & 0,42 \\
\hline U & $<0,1$ & $<0,1$ & $<0,1$ & 2,1 & 4 \\
\hline V & $<8$ & 9 & $<8$ & 29 & 55 \\
\hline W & $<0,5$ & $<0,5$ & $<0,5$ & 0,7 & $<0,5$ \\
\hline$Y$ & 2,3 & 6 & 4,3 & 17,1 & 27,6 \\
\hline $\mathrm{Yb}$ & 0,21 & 0,47 & 0,26 & 1,43 & 2,57 \\
\hline $\mathrm{Zr}$ & 0,5 & 3 & 1,8 & 41,2 & 186,1 \\
\hline Mo & 0,2 & 0,1 & 0,1 & 0,8 & 0,2 \\
\hline $\mathrm{Cu}$ & 0,7 & 0,7 & 0,8 & 1,2 & 1,4 \\
\hline $\mathrm{Pb}$ & 2,6 & 1,2 & 1 & 2,6 & 2,6 \\
\hline $\mathrm{Zn}$ & 3 & 16 & 6 & 12 & 13 \\
\hline $\mathrm{Ni}$ & 0,5 & 1,2 & 0,8 & 17,4 & 13 \\
\hline As & 1,6 & 0,7 & 0,5 & $<0,5$ & $<0,5$ \\
\hline $\mathrm{Cd}$ & $<0,1$ & $<0,1$ & $<0,1$ & $<0,1$ & $<0,1$ \\
\hline $\mathrm{Sb}$ & 0,3 & 0,1 & $<0,1$ & $<0,1$ & $<0,1$ \\
\hline $\mathrm{Ag}$ & $<0,1$ & $<0,1$ & $<0,1$ & $<0,1$ & $<0,1$ \\
\hline
\end{tabular}


Tabela 2. Continuação.

\begin{tabular}{|c|c|c|c|c|c|c|c|c|c|}
\hline BS-PAAS & BSA-019 & BSA-001 & BSA-011 & BSA-018 & BSA-006 & BSA-010 & BSA-013 & BSA-003 & BSA-020 \\
\hline EETR & 14,750 & 5,720 & 7,950 & 15,800 & 9,920 & 11,440 & 5,320 & 15,640 & 10,700 \\
\hline $\mathrm{Pr} \mathrm{Yb}_{\mathrm{SNH}}$ & 0,183 & 0,176 & 0,166 & 0,186 & 0,233 & 0,164 & 0,122 & 0,231 & 0,246 \\
\hline $\mathrm{Sm} / \mathrm{Yb}_{(\mathrm{SN})}$ & 0,311 & 0,305 & 0,245 & 0,296 & 0,274 & 0,223 & 0,266 & 0,346 & 0,332 \\
\hline $\mathrm{Ce} / \mathrm{Ce}^{*}$ & 0,845 & 0,602 & 0,732 & 0,804 & 0,634 & 0,689 & 0,794 & 0,713 & 0,684 \\
\hline $\operatorname{Pr} / \operatorname{Pr}^{\star}$ & 0,928 & 1,005 & 0,932 & 0,958 & 0,985 & 0,968 & 0,615 & 1,007 & 0,849 \\
\hline $\mathrm{Eu} / \mathrm{Eu}^{*}$ & 1,551 & 1,369 & 1,993 & 1,454 & 1,707 & 1,300 & 1,432 & 1,411 & 1,242 \\
\hline $\mathrm{Y} / \mathrm{Ho}$ & 43,571 & 48,000 & 50,000 & 43,125 & 46,667 & 51,000 & 46,000 & 42,857 & 53,750 \\
\hline La/La* & 2,334 & 2,660 & 2,367 & 2,071 & 2,413 & 2,295 & $-0,927$ & 1,829 & 5,263 \\
\hline $\mathrm{Nd} / \mathrm{Nd}^{*}$ & 0,936 & 0,866 & 0,901 & 0,942 & 1,010 & 0,945 & 1,430 & 0,859 & 1,107 \\
\hline$Y / Y^{*}$ & 1,837003 & 1,784928 & 2,164444 & 1,790955 & 2,036292 & 2,231618 & 1,710556 & 1,623541 & 2,232205 \\
\hline
\end{tabular}

topo da FFB Bom Sucesso (xisto ferruginoso) devido à falta de dados geoquímicos relacionados à unidade de topo do Grupo Itabira, o Grupo Piracicaba.

\section{Isótopos de $\mathrm{U}-\mathrm{Pb}$}

As razões isotópicas foram obtidas pelo equipamento New Wave 213 Laser Ablation System (LA), acoplado ao Agilent 7700 ICPMS do Departamento de Geologia (Degeo) da Universidade Federal de Ouro Preto (UFOP). A técnica aplicada é mesma desenvolvida por Lana et al. (2011), Romano et al. (2012) e Buick et al. (2011). O instrumento foi calibrado para maior detecção alternada das massas 204, 206, 207, 232, 238 usandose dwell times 10, 15, 40, 10, 15 (ms), respectivamente. $\mathrm{O}$ nível de reprodutibilidade e precisão foram constantemente testados utilizando-se padrões internacionais como o 609 Ma Gemoc (Jackson et al., 2004) e $337 \mathrm{Ma}$ Plessovice (Sláma et al., 2008). Tanto os padrões como as amostras de zircão foram perfurados sob as mesmas condições de energia e frequência do laser. O spot size adotado foi de $30 \mu \mathrm{m}$.

Efeitos de mass bias instrumental e fracionamento por ablação foram externamente corrigidos usando-se padrões minerais compatíveis com as matrizes dos minerais amostrados. Tal correção e conversão dos dados para razões $\mathrm{Pb} / \mathrm{Pb}, \mathrm{U} / \mathrm{Pb}$ e $\mathrm{Th} / \mathrm{Pb}$ foram feitas por meio do programa Glitter.

Como preparação para as análises LA-ICPMS, foi feito intenso uso de fotomicrografia sob luz transmitida e refletida junto com imageamento por catodoluminescência (CL), utilizando-se microssonda eletrônica de varredura (MEV), para detalhar complexidades no crescimento de cristais de zircão e determinar as melhores áreas para análises in situ. Toda a preparação de amostras foi efetuada no Degeo, e as imagens de CL foram realizadas no Instituto de Geociências da Universidade de São Paulo (IGc/USP).

\section{SEQUÊNCIA METASSEDIMENTAR BOM SUCESSO}

A Sequência Metassedimentar Bom Sucesso é subdividida, da base para o topo, em três pacotes litológicos: Lagoa da Prata, FFB Bom Sucesso e Tabuãozinho (Figura 2). Essas unidades estão dispostas como faixas de direção predominantemente NE-SW, que definem a morfologia da Serra de Bom Sucesso. Em uma faixa ligeiramente alongada, adjacente à encosta leste da Serra de Bom Sucesso, afloram xistos do Greenstone Belt Rio das Mortes, embora o contato entre os litotipos não seja aflorante. Todas as unidades supracitadas estão intrudidas pelo Granito Tabuões, que faz parte do conjunto de plútons graníticos e tonalíticos paleoproterozoicos.

O xisto do Greenstone Belt Rio das Mortes tem textura nematoblástica com mineralogia essencial composta por tremolita e plagioclásio muito epidotizado com cristais orientados segundo a foliação principal. Próximo aos contatos com o Granito Tabuões, ocorre antofilita granada xisto, com granada de granulação média a grossa (> 2,00 mm) e alongada segundo a foliação principal. Esse xisto é composto por antofilita, cummingtonita-grunerita, granada, cordierita e quartzo, com antofilita ocorrendo em textura decussada.

A rocha do Granito Tabuões é metamorfisada e possui foliação penetrativa, com cristais de quartzo elongado, feldspatos e biotita orientados. Os principais constituintes minerais são quartzo, plagioclásio, ortoclásio, microclina e biotita, com trama variando de granolepidoblástica a granoblástica.

A Unidade Lagoa da Prata aflora na vertente oeste da Serra de Bom Sucesso e possui espessura mínima estimada em 200 m. Na base dessa unidade, ocorre uma sequência de mica xisto, quartzo-mica xisto, mica-quartzo xisto, quartzito micáceo e quartzito, em geral de granulação fina $(0,01$ a $1,00 \mathrm{~mm})$. Os minerais essenciais são quartzo, biotita e muscovita, em diferentes proporções, com eventual ocorrência de turmalina, além de opacos como acessórios. No topo, em contato transicional, ocorre xisto carbonático 

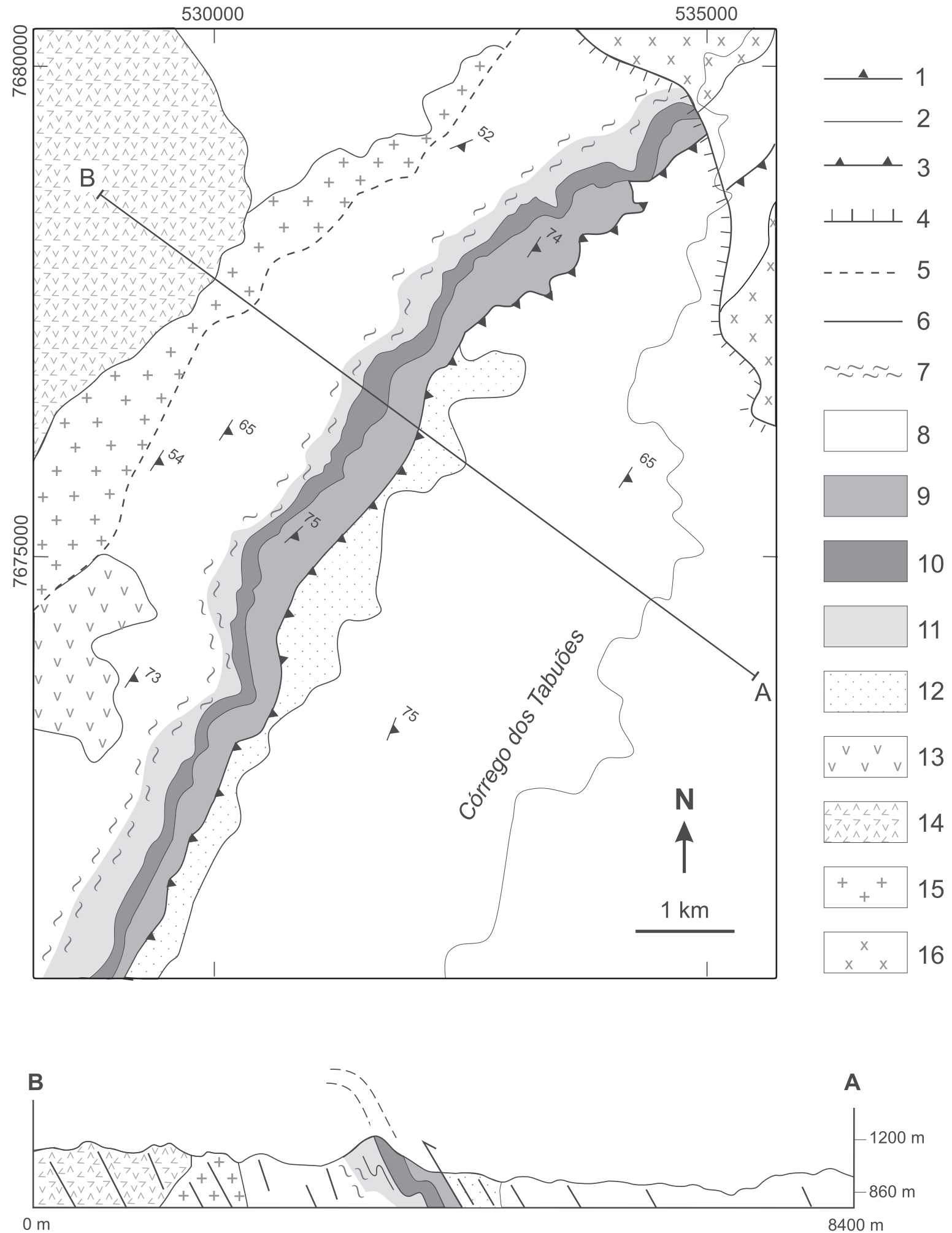

1: foliação principal (S1); 2: contato litológico; 3: falha de empurrão; 4: falha normal; 5: falha de alto ângulo indiscriminada; 6: perfil; 7: contato cisalhado; 8: Granito Tabuões; 9: Unidade Tabuãozinho; 10: Unidade Formação Ferrífera Bandada Bom Sucesso; 11: Unidade Lagoa da Prata; 12: Greenstone Belt Rio das Mortes; 13: meta-anortosito; 14: Granito Bom Sucesso; 15: anfibolito; 16: gnaisse.

Figura 2. Mapa geológico da porção norte da Serra de Bom Sucesso e perfil de detalhe AB. 
grafitoso, de granulação fina $(0,01$ a $0,7 \mathrm{~mm})$, com cristais de carbonato e grafita elongados que definem a foliação principal e lineação mineral.

A Unidade FFB Bom Sucesso tem, ao longo da serra, espessura aparente variável entre 25 e aproximadamente $250 \mathrm{~m}$. O contato com a Unidade Lagoa da Prata é gradacional, definido pela intercalação métrica a centimétrica de xisto carbonático grafitoso e FFB. A FFB é predominantemente caracterizada pela intercalação de bandas de óxido de ferro e bandas de anfibólio. Em menor proporção, é comum ocorrer também níveis quartzosos paralelos ao bandamento composicional. Observam-se, em furos de sondagem, intercalações de dolomito ferruginoso bandado. No topo da unidade, a FFB grada para um xisto ferruginoso com porções granatíferas descontínuas.

A Unidade Tabuãozinho aflora na vertente leste da Serra de Bom Sucesso, tem espessura mínima estimada em $250 \mathrm{~m}$ e está em contato transicional com o xisto ferruginoso. Essa Unidade é caracterizada, da base para o topo, por uma sequência de hornblenda-clorita xisto, clorita xisto e biotita-muscovita xisto, com porções descontínuas de granada-muscovita xisto e granada-clorita xisto.

\section{ELEMENTOS ESTRUTURAIS}

Regionalmente, a estruturação da Serra de Bom Sucesso é controlada por dois lineamentos estruturais fotointerpretados. Um lineamento, com direção NW-SE, trunca a extremidade nordeste da Serra de Bom Sucesso e define o contato lateral da Sequência Metassedimentar Bom Sucesso com o embasamento arqueano. O outro, de direção NE-SW, trunca e limita as unidades arqueanas e granitos paleoproterozoicos a oeste da Serra de Bom Sucesso (Figura 2). Em escala de mapeamento e afloramento, a estruturação é definida pelo contato litológico entre as unidades que se reflete no bandamento composicional $\left(\mathrm{S}_{\mathrm{b}} \equiv \mathrm{S}_{0}\right)$ da Unidade FFB Bom Sucesso e localmente na Unidade Tabuãozinho, definido pela alternância de níveis de diferente composição mineralógica. De modo geral, $\mathrm{S}_{0}$ tem direção NE-SW com mergulhos variáveis para SE (Figura 3A), apresentando uma primeira geração de dobras intrafoliais $\left(D_{1}\right)$, fechadas a isoclinais, com vergência para NW, ocorrendo em escala tanto centimétrica quanto métrica e eixos variáveis no plano axial desde NE, horizontal até paralela à linha de maior declividade (Figura 3B).

Em afloramento, entretanto, a principal estrutura observada é uma xistosidade $\left(\mathrm{S}_{1}\right)$ planoaxial às dobras $\mathrm{D}_{1}$, caracterizada principalmente pela orientação dos minerais placoides, observada em quase todos os litotipos mapeados e que geralmente transpõe e oblitera o bandamento $\left(\mathrm{S}_{\mathrm{b}} \equiv \mathrm{S}_{\mathrm{o}}\right)$. $\mathrm{S}_{1}$ possui predominantemente direção NE-SW mergulhando para SE (Figura 3C), mas encontra-se suavemente dobrada por estruturas de uma segunda geração $\left(\mathrm{D}_{2}\right)$. As dobras
$\mathrm{D}_{2}$ são abertas, de escala métrica, com vergência NW, eixos predominantemente de orientação NE-SW e caimento suave, sub-horizontal tanto para NE quanto para SW (Figura 3D). Pequenas variações no alinhamento dos eixos $\left(\mathrm{D}_{2}\right)$, com direções variando de SSW a W, e a dispersão das medidas de polos dos planos de xistosidade $\left(\mathrm{S}_{1}\right)$ para $\mathrm{SW}$ indicam uma terceira geração de dobras $\left(\mathrm{D}_{3}\right)$, suaves, em escala hectamétrica e eixo calculado caindo $45^{\circ}$ para NE.

O limite da Sequência Metassedimentar Bom Sucesso a leste é definido por uma zona de cisalhamento que corre subparalela aos planos de contato litológico e é caracterizada pelo maior desenvolvimento da foliação $S_{1}$ que adquire feições associadas à milonitização $\left(S_{\text {mil }} \equiv S_{1}\right)$, com obliteração total do bandamento, formação de estruturas $\mathrm{S}-\mathrm{C}$, bandas de cisalhamento e faixas filoníticas, além de grande quantidade de veios de quartzo de morfologia sigmoidal. Nos planos de foliação, desenvolve-se lineação de estiramento mineral com caimento de baixo ângulo para NE (Figura 3E). A oeste, a sequência é limitada pelo contato cisalhado com o Granito Tabuões.

Falhas normais de alto ângulo e direção paralela à macroestrutura são encontradas tanto em escala de afloramento quanto em furos de sondagem e levam a supor a existência de movimentos de caráter extensional com possível reativação dos planos de cavalgamento, talvez reflexo da fase de colapso (Alkmim e Marshak, 1998) ou de reajuste isostático.

A terceira geração de dobras $\left(\mathrm{D}_{3}\right)$, inferida, pode estar relacionada à deformação brasiliana, descrita regionalmente por Quéméneuer et al. (2003) como sendo de intensidade decrescente de sul para norte.

\section{PETROGRAFIA E MINERALOGIA DA UNIDADE FORMAÇÃO FERRÍFERA BANDADA BOM SUCESSO}

\section{Caracterização da mineralogia magnética}

As observações ao microscópio ótico confirmam que os óxidos de ferro presentes na FFB Bom Sucesso têm cor característica de hematita, mas macroscopicamente são magnéticos, sugerindo magnetita ou maghemita como mineral mais provável. Para melhor caracterizar a mineralogia magnética, foram determinadas curvas termomagnéticas (suscetibilidade magnética em função da temperatura) de dez amostras de FFB. A transição do estado ferrimagnético para o estado antiferrimagnético, ponto de inflexão no gráfico, é chamada de temperatura de Curie e, para substâncias paramagnéticas, de temperatura de Neel. Similarmente, o ponto de Verwey (ferrimagnéticos) e Morin (paramagnéti$\cos$ ) caracteriza essa transição de estados em baixas temperaturas. Segundo Dunlop e Özdemir (1997), a transição de Verwey e Curie ocorre na magnetita a -153 e $580^{\circ} \mathrm{C}$ e, na hematita, a -15 e $680^{\circ} \mathrm{C}$. A maghemita possui temperaturas 

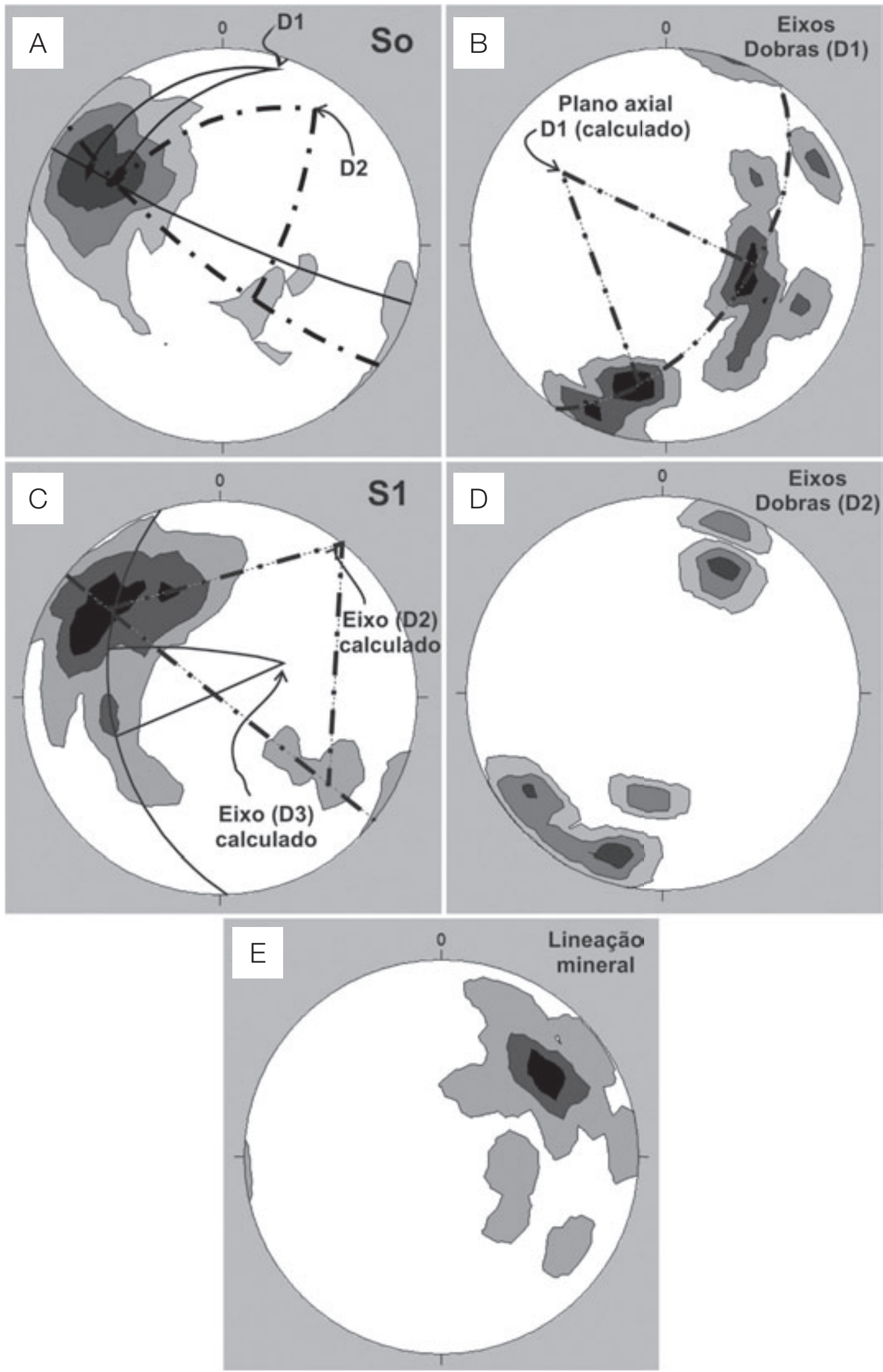

Figura 3. Diagrama de igual área, hemisfério inferior. (A) polos de planos de acamamento So medidos e eixos de dobras (D1 e D2) calculados; (B) eixos de dobras (D1) medidos e plano de rotação coincidente com plano axial (D1) calculado; (C) eixos calculados de dobras (D2 e D3); (D) polos de planos de xistosidade S1 medidos e eixo de dobra (D2) calculado; (E) lineação de estiramento mineral. 
de transição variáveis, com parâmetros termomagnéticos variando de valores próximos aos apresentados na magnetita até os valores apresentados na hematita. Segundo Deer et al. (1992), a maghemita é metaestável e é transformada em hematita por aquecimento, com temperatura de inversão variando de 200 a $700^{\circ} \mathrm{C}$.

O óxido de ferro na FFB Bom Sucesso pode ocorrer de duas formas:

1) Cristais idiomórficos a hipidiomórficos, individualmente ou constituindo agregados (Figura 4A).

2) Cristais xenoblásticos alongados, orientados segundo a foliação da rocha (Figura 4B).

A granulação é variável, de muito fina a média $(<0,01$ a $1,20 \mathrm{~mm})$, e as curvas termomagnéticas de 10 amostras de FFB mostram que são desmagnetizados em torno de 620 e $-138^{\circ} \mathrm{C}$ (Figuras $4 \mathrm{C}$ e D), indicando o mineral maghemita (Gehring et al., 2009). Localmente, em análises de lâminas delgadas polidas, foi observada a presença de relictos de magnetita, que se distingue da maghemita pela cor cinza escura ou ocorrendo como cristais subédricos a euédricos (Figura 4E).

\section{Formação Ferrífera Bandada}

A FFB compõe a maior parte da unidade e caracteriza-se pela intercalação, milimétrica a centimétrica, de níveis de óxido de ferro, silicatos e quartzo.

A mineralogia dos níveis silicáticos é constituída predominantemente por anfibólios da série cumingtonita-grunerita (Figura 4F), de granulação de densa a fina $(0,02$ a $0,9 \mathrm{~mm})$, e, subordinadamente, tremolita-ferro-actinolita de granulação fina $(\sim 0,2 \mathrm{~mm})$, intercalados com níveis quartzosos que definem o bandamento. Os níveis de quartzo contêm maghemita de granulação muito fina disseminada. É comum ocorrer hedenbergita, ferroaugita, hornblenda, almandina e turmalina como mineralogia principal. Biotita, carbonato, apatita, talco, microclina, andradita, pirita e ortopiroxênio da série enstatita-ferrosilita ocorrem como minerais acessórios. Os orto e clinopiroxênios geralmente são relictos nos níveis anfibolíticos, mas ocorrem também como níveis compondo o bandamento, de granulação média (até $6 \mathrm{~mm}$ ), crescidos sobre o microbandamento definido pela maghemita e contendo inclusões de microclina e quartzo.

\section{Dolomito Ferruginoso}

O Dolomito Ferruginoso ocorre como corpos delgados ( $<5 \mathrm{~m}$ de espessura), descontínuos, intercalados à FFB, geralmente na base da unidade. É caracterizado pela intercalação milimétrica a centimétrica de níveis enriquecidos em maghemita e bandas de dolomita. A mineralogia principal é composta por dolomita, maghemita e tremolita. A granulação é densa a fina $(0,01$ a $0,1 \mathrm{~mm})$, com cristais de dolomita geralmente em granulação média, e contatos interlobados a poligonais.

\section{Xisto Ferruginoso}

Esta unidade ocorre no topo, em contato transicional com a FFB. É constituída por hedenbergita, hornblenda, maghemita, biotita e quartzo e apresenta granulação fina $(0,1$ a $0,4 \mathrm{~mm}$ ). Próximo ao contato com a FFB, ocorrem ainda porções de xisto laminado granatífero, com diminutos cristais de almandina $(0,01$ a $0,1 \mathrm{~mm})$, intercalados com níveis de cumingtonita-grunerita e maghemita disseminada. O anfibólio possui granulação fina $(0,1$ a $0,8 \mathrm{~mm})$, assim como a maghemita $(0,01 \mathrm{~mm})$. Os xistos granatíferos são descontínuos e podem chegar a $5 \mathrm{~m}$ de espessura.

A FFB, em geral, tem textura nematoblástica dada pela orientação preferencial de cummingtonita-grunerita, quartzo e maghemita elongados. No entanto, é comum ocorrer porções de textura granonematoblástica, formada pela intercalação dos níveis de quartzo, com contatos poligonais a interlobados e extinção ondulante, ou por bandas ricas em maghemita subédrica a euédrica, individualmente ou constituindo agregados. O bandamento é formado por níveis de anfibólios da série tremolita-ferro-actinolita, com cummingtonita-grunerita subordinada ou ausente, agregados de maghemita e intercalação de bandas quartzosas; a textura é granoblástica, com anfibólio e óxido de ferro granular, de granulação densa a média $(<0,01$ a $1,00 \mathrm{~mm}$ ) e contatos poligonais. São observadas também porções descontínuas, em textura decussada, formadas por cummingtonita-grunerita de granulação fina a média $(0,5 \mathrm{a} 2 \mathrm{~mm})$, aciculares e crescidas sobre o bandamento de maghemita (Figura 5A).

Níveis granatíferos, descontínuos, ocorrem intercalados à $\mathrm{FFB}$, apresentam textura porfiroblástica, com blastos de granada almandina e turmalina azul. A granada tem granulação fina a média $(0,1$ até $7 \mathrm{~mm})$ e cristais subédricos a euédricos. A turmalina tem granulação densa a média $(0,05$ a $1 \mathrm{~mm}$ ) e cristais também subédricos a euédricos. A matriz é lepidoblástica formada por cummingtonita-grunerita, ferro-hornblenda e maghemita elongada. Os cristais de granada estão envolvidos pela foliação principal, mas apresentam microestrutura com poiquiloblastos orientados, indicando deflexão da foliação principal, formada por cummingtonita-grunerita, maghemita e quartzo elongados.

Cristais de hedenbergita são relictos (Figura 5B) ou compõem níveis descontínuos, centimétricos a milimétricos, intercalados à FFB, de granulação média $(\sim 6 \mathrm{~mm})$ e crescidos sobre os agregados de maghemita. A hedenbergita tem inclusões de microclina e quartzo (Figura 5C) e é parcialmente substituída, ao redor ou ao longo de 

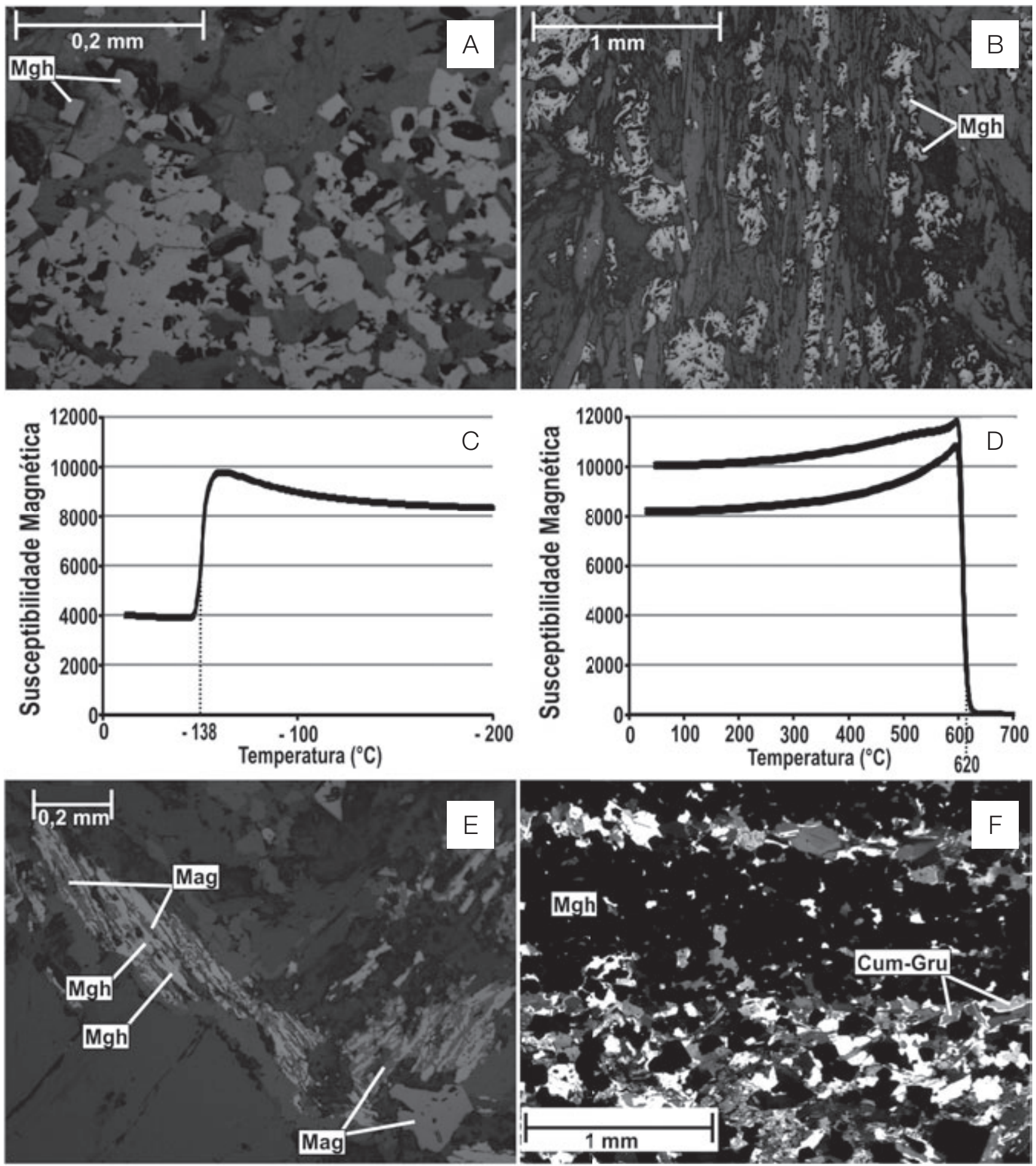

Figura 4. (A) cristais de maghemita (Mgh) idiomórficos a hipidiomórficos, constituindo agregados. Luz refletida e nicóis parcialmente cruzados; (B) Cristais de Mgh xenobláticos constituindo agregados alongados, orientados segundo a foliação da rocha. Luz refletida, nicóis parcialmente cruzados; (C) Curva termomagnética com desmagnetização em $-138^{\circ} \mathrm{C}$, amostra do furo de sondagem FDBS038 e profundidade de 53,35 m; (D) Curva termomagnética com desmagnetização em $620^{\circ} \mathrm{C}$, profundidade de 53,35 metros; (E) Cristais de magnetita (Mag) parcialmente substituídos em Mgh e cristal de Mag subédrica. Luz refletida, nicóis parcialmente cruzados; (F) Formação ferrífera anfibolítica com níveis de cummingtonita-grunerita (Cum-Gru) e Mgh. Luz transmitida, nicóis cruzados. 
microfraturas, por cristais laminados ou aciculares de cummingtonita-grunerita e/ou tremolita-ferro-actinolita. Ortopiroxênio da série enstatita-ferrossilita foi observado também parcialmente substituído por anfibólios da série tremolita-ferro-actinolita e biotita (Figura 5D).

A foliação principal $\left(\mathrm{S}_{1}\right)$ é definida pela orientação preferencial de anfibólios, maghemita e quartzo, e é, em geral, oblíqua à maior elongação dos cristais de piroxênio. O bandamento caracterizado pela alternância de níveis com cristais de piroxênio e de maghemita está parcialmente ou completamente obliterado pela presença de cummingtonita-grunerita com textura decussada.

No contato com as apófises do Granito Tabuões, a FFB é composta por ferro-augita, cummingtonita-grunerita, ferro-hornblenda, magnetita, pirita e/ou pirrotita, ocorrendo todos orientados segundo a foliação principal. Ferroaugita ocorre como relicto e está parcialmente substituído por cummingtonita-grunerita e ferro-hornblenda.

\section{METAMORFISMO DAS FORMAÇÕES FERRÍFERAS}

Relacionando as associações mineralógicas presentes na FFB Bom Sucesso às típicas zonas metamórficas barrovianas, caracterizadas por Best (2003), para metamorfismo em rochas pelíticas, e por Klein (2005), para metamorfismo em FFB pré-cambrianas, a associação mineral hedenbergita + microclina \pm enstatita-ferrossilita \pm ferro-augita sugere condições de metamorfismo na zona da sillimanita-álcali-feldspato. A associação mineral cummingtonitagrunerita \pm tremolita-ferro-actinolita \pm biotita \pm almandina \pm ferro-hornblenda, que trunca os níveis de piroxênios com granulação muito grossa e define a foliação principal, sugere reações retrometamórficas em condições da zona da granada, que corresponde ao fácies anfibolito.

A Unidade Lagoa da Prata, base da FFB, apresenta associação mineral biotita + muscovita \pm dolomita, que indica condições do tipo barroviano na zona da biotita (fácies xisto verde). No entanto, na Unidade Tabuãozinho, topo da sequência, a associação hornblenda + biotita + muscovita + clorita \pm almandina indica metamorfismo em condições da zona da granada.

Os dois litotipos observados do Greenstone Belt Rio das Mortes, ocorrentes na área mapeada, contêm associação mineral dada por tremolita + plagioclásio + epidoto, que indicam fácies anfibolito médio, e antofilita cummingtonita-grunerita + granada + cordierita, que indicam fácies anfibolito alto (Bucher e Grapes, 2011).

O Granito Tabuões apresenta uma associação mineral composta por plagioclásio + microclina + ortoclásio + biotita + muscovita + piroxênio, indicativa de fácies anfibolito (Yardley, 2004).

\section{VEIOS NA SEQUÊNCIA METASSEDIMENTAR BOM SUCESSO}

A Sequência Metassedimentar Bom Sucesso contém marcante presença de vênulas e veios quartzosos e/ou carbonáticos. Estes ocorrem tanto concordantes quanto discordantes com o bandamento composicional, mas comumente alojados nos planos da foliação principal. Apresentam espessura milimétrica a métrica, encontrando-se frequentemente dobrados, estirados e/ou rotacionados e com morfologia sigmoidal. Mineralogicamente, são compostos por cristais de tamanho variado $(<0,01 \mathrm{a} 1,00 \mathrm{~mm}): \pm$ carbonato \pm quartzo \pm almandina \pm maghemita \pm pirita e \pm pirrotita.

Em geral, os veios são compostos por carbonato ou quartzo, em maior proporção, e maghemita, almandina, pirita e pirrotita subordinados. No entanto, é comum ocorrerem veios com granada almandina, com quartzo e carbonato subordinados (Figura 6). Pirita e/ou pirrotita ocorrem concentrados nos veios, nas proximidades do contato da FFB com as apófises do Granito Tabuões.

No contato dos veios com a FFB, a cummingtonitagrunerita ocorre com granulação grossa $(\sim 1 \mathrm{~mm})$ e textura decussada. A hedenbergita, com granulação muito grossa (> $5 \mathrm{~mm}$ ), tem inclusões de microclina e apresenta substituição marginal de ferro-actinolita acicular e carbonato. Localmente, observa-se substituição de hedenbergita por ferro-actinolita e diminutos cristais de andradita e biotita.

Nos veios onde há predomínio de carbonato, a maghemita ocorre disseminada como cristais euédricos a subédricos, de granulação média a grossa $(0,01 \mathrm{a} 1,00 \mathrm{~mm})$. Nos veios com predomínio de quartzo, ela ocorre como cristais individuais anédricos, com granulação fina a média $(0,01$ a $0,1 \mathrm{~mm})$, ou constituindo agregados de minerais dispostos paralelamente à borda dos veios.

\section{GEOQUÍMICA}

\section{Elementos maiores}

A FFB da Serra de Bom Sucesso contém teores de $\mathrm{Fe}_{2} \mathrm{O}_{3}$ (44,63 - 50,48\%), $\mathrm{SiO}_{2}(42,42-47,36 \%), \mathrm{Fe}_{\text {total }}(17,85-$ $20,19 \%), \mathrm{CaO}(0,36-6,04 \%), \mathrm{MgO}(2,59-6,21 \%), \mathrm{MnO}$ $(0,10-0,24 \%)$ e $\mathrm{Al}_{2} \mathrm{O}_{3}(0,02-0,20 \%)$ muito similares aos itabiritos do tipo anfibolítico e silicoso da Formação Cauê, Supergrupo Minas no Quadrilátero Ferrífero (Figura 7A). A diferença se dá pelo elevado conteúdo de álcalis, $\mathrm{Na}_{2} \mathrm{O}$ $(0,02-1,27 \%)$ e $\mathrm{K}_{2} \mathrm{O}(0,02-0,73 \%)$.

O Xisto Ferruginoso, topo da unidade FFB Bom Sucesso, contém teores de $\mathrm{SiO}_{2}(48,77-56,57 \%), \mathrm{Al}_{2} \mathrm{O}_{3}(5,03-$ $11,00 \%), \mathrm{Na}_{2} \mathrm{O}(0,03-0,18 \%), \mathrm{P}_{2} \mathrm{O}_{5}(0,08-0,11 \%)$ e $\mathrm{TiO}_{2}$ $(0,18-0,51 \%)$ semelhantes aos teores apresentados no filito sericítico, caracterizados por Spier et al. (2007); o filito 


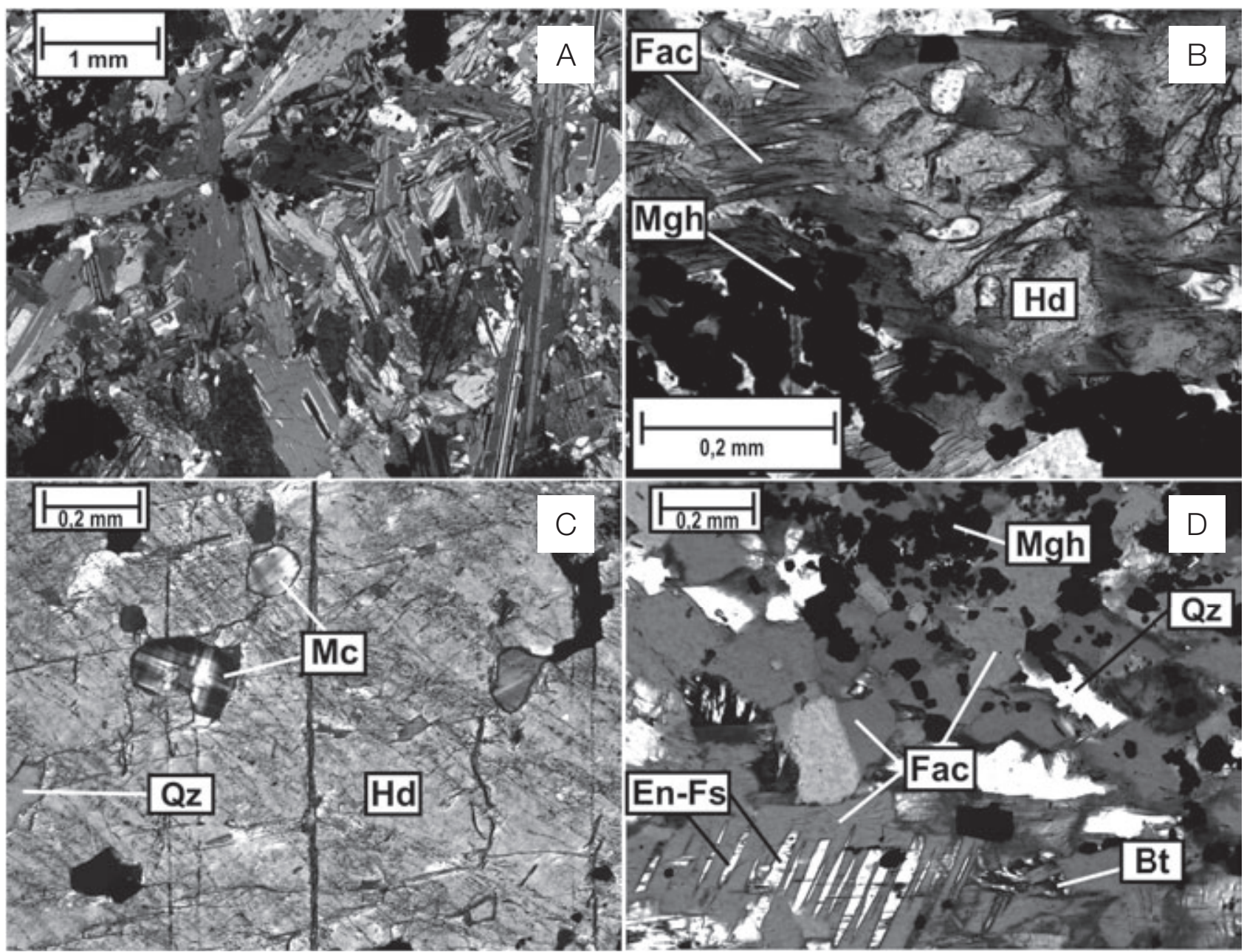

Figura 5. Fotomicrografias em luz transmitida. (A) Cummingtonita-grunerita (Cum-Gru) de granulação grossa e textura decussada (B) Relicto de cristal de hedenbergita (Hd) parcialmente substituído por ferro-actinolita acicular (Fac); (C) Cristal de hedenbergita (Hd) de granulação muito grossa com inclusão de microclina (Mc) e quartzo (Qz); (D) enstatita-ferrossilita (En-Fs) parcialmente substituída por ferro-actinolita (Fac) e biotita (Bt), com textura granoblástica e presença de quartzo (Qz) e maghemita (Mgh).

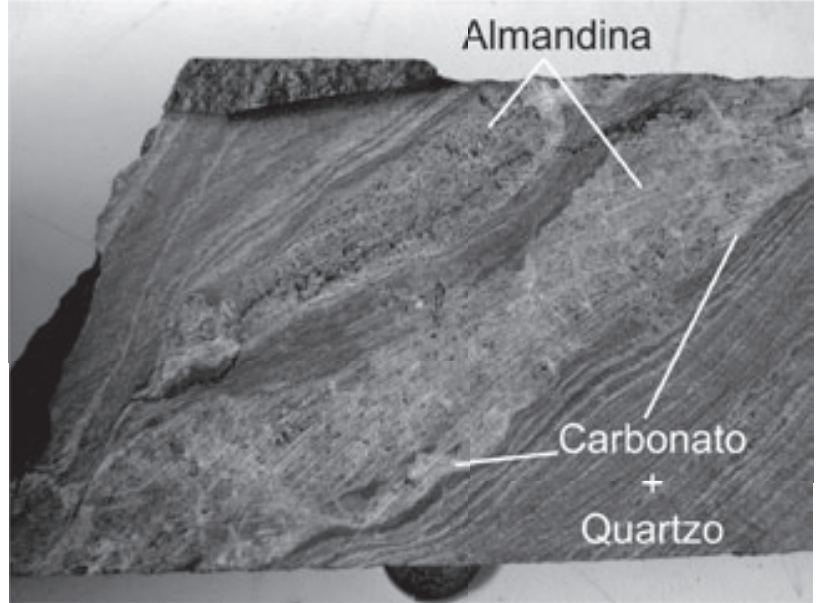

Figura 6. Veio com granada almandina predominante, com quartzo e carbonato subordinados, subparalelo ao bandamento. sericítico é o litotipo da Formação Batatal, unidade basal ao Grupo Itabira no Supergrupo Minas (Figura 7B). No entanto, o Xisto Ferruginoso contém os teores de $\mathrm{Fe}_{2} \mathrm{O}_{3}(20,44-$ $30,43 \%), \mathrm{Fe}_{\text {total }}(8,18-12,17 \%), \mathrm{CaO}(2,80-3,86 \%), \mathrm{MgO}$ $(2,95-9,3 \%)$ e $\mathrm{MnO}(0,19-6,32 \%)$ mais elevados.

Peter (2003) usa as razões $\mathrm{Fe} / \mathrm{Ti}$ e $\mathrm{Al} /(\mathrm{Al}+\mathrm{Fe}+\mathrm{Mn})$ para relacionar a contribuição hidrotermal e detrítica nos sedimentos de uma bacia. As razões das amostras analisadas (Figura 8) indicam um trend contínuo com fases predominantemente hidrotermais (FFB) e uma transição para fases com maior contribuição detrítica (xisto ferruginoso). Os teores da FFB da Serra de Bom Sucesso produzem razões dentro da faixa de valores do itabirito anfibolítico e silicoso da Formação Cauê e ambos possuem razões próximas a sedimentos metalíferos da dorsal meso-oceânica do Pacífico. Os valores encontrados no xisto ferruginoso têm razões $\mathrm{Al} /(\mathrm{Al}+\mathrm{Fe}+\mathrm{Mn})$ muito distantes das apresentadas no filito sericítico da Formação Batatal e em argilas 
pelágicas do Pacífico e razões semelhantes a sedimentos de fundo oceânico com pequena participação de detritos continentais.

\section{Elementos Traço}

Peter (2003) utiliza vários diagramas de covariação interelementar e procedimentos estatísticos para caracterizar as relações geoquímicas e a origem de vários elementos traço em formações ferríferas. O autor relaciona a covariação interelementar, a concentração dos elementos e a origem dos elementos traço, discriminando end members (membros extremos): elementos de origem hidrotermal, de origem detrítica e de transição (Figura 9).

Considerando-se os critérios desse autor, a FFB da Serra de Bom Sucesso, normalizada ao padrão da crosta superior (UCC, do inglês Upper Continental Crust; Taylor e McLennan, 1985), é relativamente mais enriquecida em $\mathrm{Rb}$, Cs e Sr, elementos de transição, e em Mo, Sb e As, elementos hidrotermais, do que em elementos detríticos
A

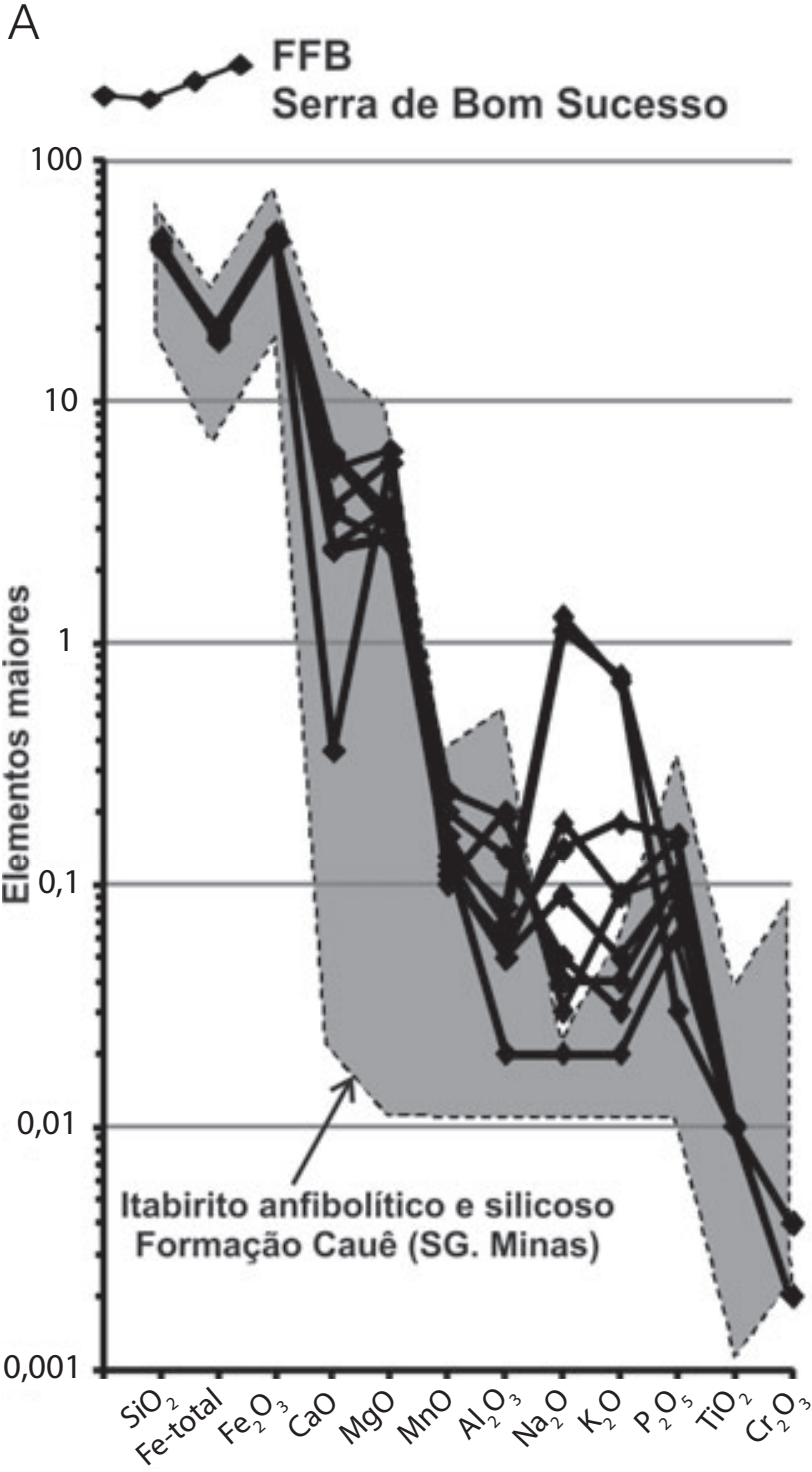

$B$
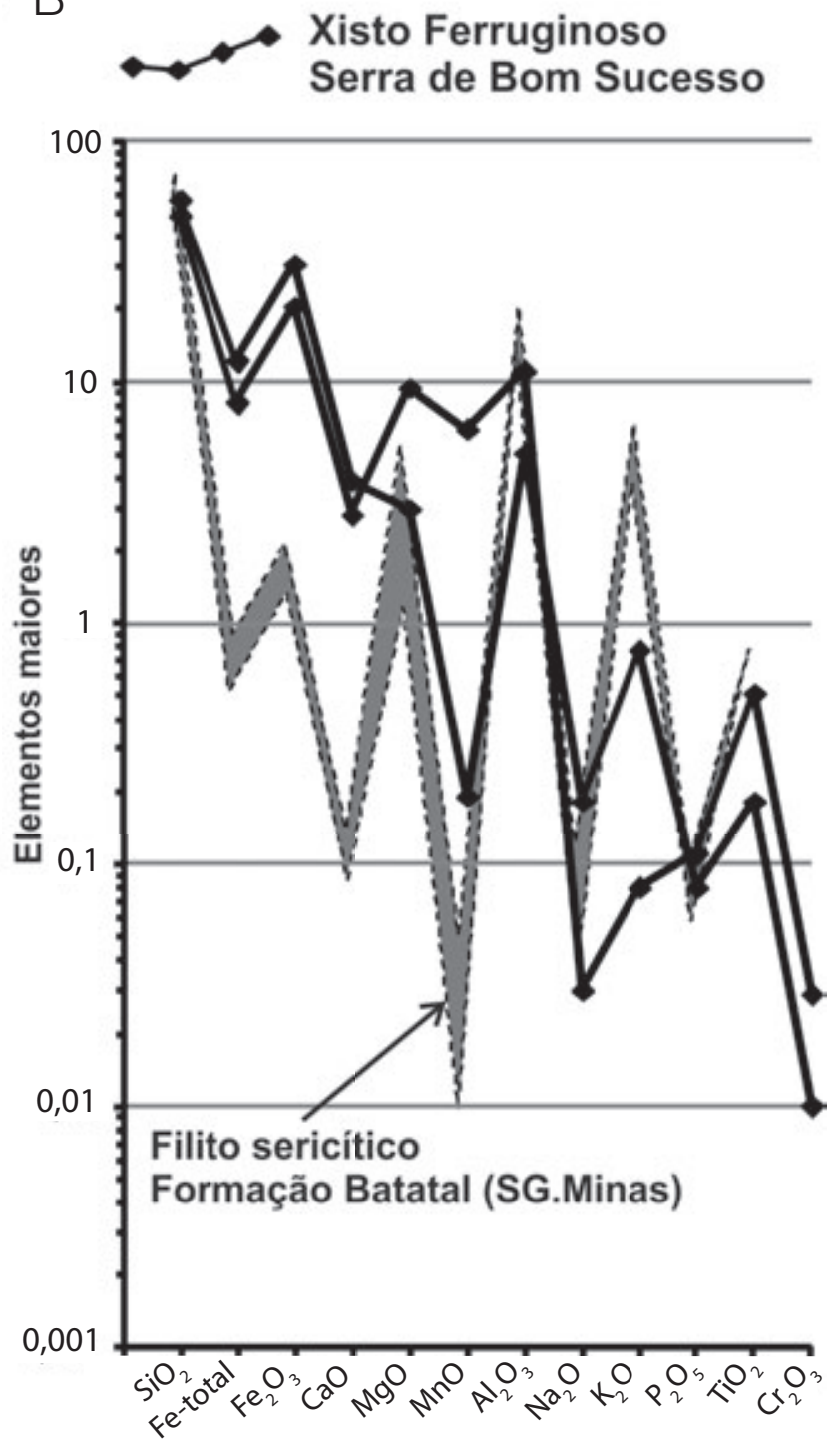

SG.: Supergrupo.

Figura 7. Concentração de elementos maiores. (A) formação ferrífera bandada (FFB) da Serra de Bom Sucesso em comparação com o Itibirito anfibolítico e silicoso da Formação Cauê; (B) Xisto Ferruginoso da Serra de Bom Sucesso em comparação com Filito Sericítico da Formação Batatal. 
(Figura 10A). Todos os elementos estão empobrecidos em relação à crosta superior, e suas concentrações estão dentro da faixa de valores apresentados nos itabiritos da Formação Cauê.

Tanto o xisto ferruginoso da Serra de Bom Sucesso quanto o filito sericítico da Formação Batatal apresentam assinatura de crosta superior, embora os dados geoquímicos indiquem maior proporção em elementos de transição e hidrotermais no filito Batatal (Figura 10B).

\section{Elementos Terras Raras}

Quando normalizadas ao PAAS, o padrão de ETR da FFB da Serra de Bom Sucesso é caracterizado por um leve enriquecimento dos elementos terras raras pesados (ETRP) em relação aos elementos terras raras leves (ETRL) $\left(\mathrm{Pr} / \mathrm{Yb}_{\mathrm{SN}}=0,12-0,26\right)$ e elementos terras raras medianos $(\mathrm{ETRM})\left(\mathrm{Sm} / \mathrm{Yb}_{\mathrm{SN}}=0,22-0,35\right)$. Os diagramas apresentam anomalias positivas de $\mathrm{Eu}(\mathrm{Eu} /$ $\left.\mathrm{Eu}^{*}=1,24-1,99\right), \mathrm{La}\left(\mathrm{La} / \mathrm{La}^{*}=1,829-5,263\right)$ e $\mathrm{Y}$ $\left(\mathrm{Y} / \mathrm{Y}^{*}=1,62-2,23\right)$. As amostras analisadas contêm concentrações relativas de ETR $+\mathrm{Y}$ dentro da faixa de valores apresentados nos itabiritos da Formação Cauê e outras FFB depositadas em ambiente bacinal (Bau e Dulski, 1996). Ambas as litologias possuem valores de anomalias positivas de Eu, La e Y muito similares, assim

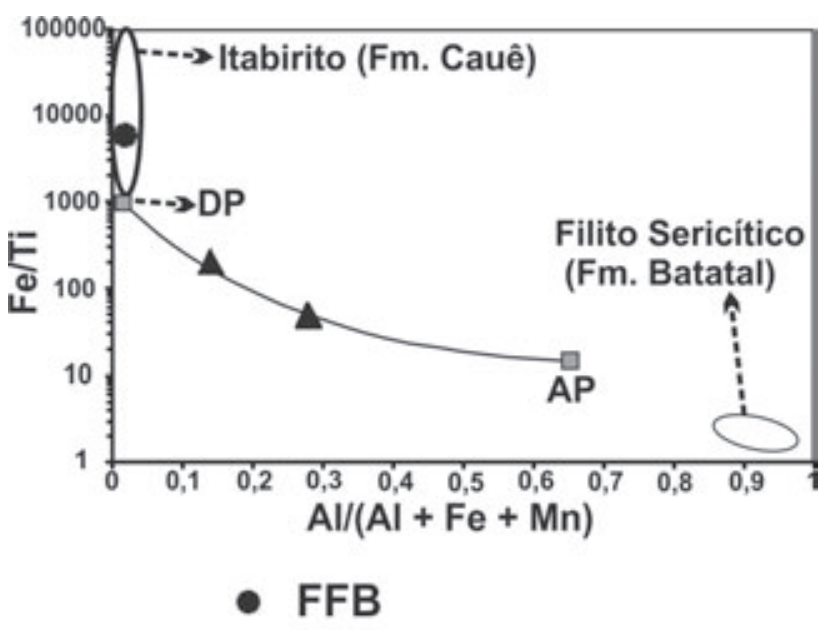

Fm.: Formação.

\section{A Xisto ferruginoso}

Figura 8. Relação das razões $\mathrm{Fe} / \mathrm{Ti}$ e $\mathrm{Al} /(\mathrm{Al}+\mathrm{Fe}+\mathrm{Mn}) \mathrm{da}$ formação ferrífera bandada (FFB) e xisto ferruginoso, da Serra de Bom Sucesso, em comparação com os campos de valores apresentados nos itabiritos da Formação Cauê, no filito sericítico da Formação Batatal, nos sedimentos metalíferos da dorsal meso-oceânica do Pacífico (DP - Peter, 2003) e nas argilas pelágicas do Pacífico (AP - Peter, 2003). como o mesmo enriquecimento relativo dos ETR pesados (Figura 11A).

O xisto ferruginoso da Serra de Bom Sucesso, assim como o filito sericítico da Formação Batatal, contém uma concentração relativa de ETR $+\mathrm{Y}$ típica de pelitos (valores normalizados próximo a 1), embora uma amostra de xisto ferruginoso esteja ligeiramente exaurida em ETR $+Y$, com pequena anomalia positiva de $\mathrm{Y}\left(\mathrm{Y} / \mathrm{Y}^{*}=1,14\right)$ e suave anomalia negativa de $\mathrm{Eu}$ $\left(\mathrm{Eu} / \mathrm{Eu}^{*}=0,90\right)$. Diferentemente, o filito Batatal não apresenta anomalia de $\mathrm{Y}$ e contém pronunciada anomalia positiva de Eu (Figura 11B). As anomalias de Nd, $\mathrm{Sm}$ e Tm observadas em uma das amostras do xisto ferruginoso são provavelmente produto de erros analíticos, visto que sedimentos pelíticos de fundo oceânico, pós-arqueanos, normalmente não apresentam anomalias nesses elementos.

\section{IDADE DA SEQUÊNCIA}

\section{Estudos prévios}

Diversos estudos geocronológicos têm sido desenvolvidos com a finalidade de limitar a idade de deposição dos sedimentos na Bacia Minas. Machado et al. (1996), analisando zircões detríticos de quatro amostras de quartzitos da base do Grupo Caraça (Formação Moeda), determinam os valores mais baixos encontrados, $2651 \pm 33 \mathrm{Ma}$ e $2606 \pm 47 \mathrm{Ma}$, como sendo a idade máxima de deposição. Igualmente, Hartmann et al. (2006) determinam uma

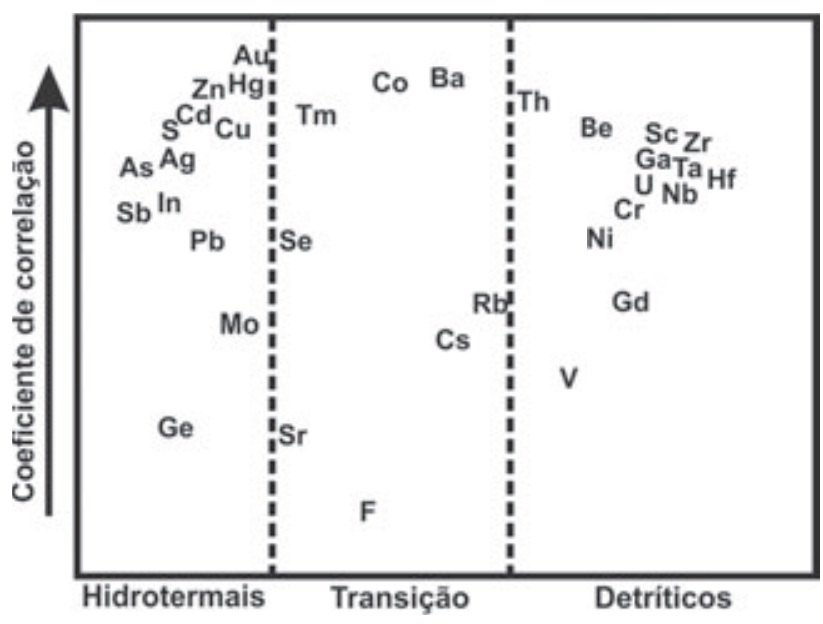

Figura 9. Diagrama adaptado de Peter (2003): relação entre o índice de correlação interelementar e a fonte dos elementos traço de formações ferríferas, discriminando elementos essencialmente hidrotermais, de transição e detríticos. 
idade máxima de deposição para a Formação Moeda de $2580 \pm 7$ Ma. Babinski et al. (1993) dataram rochas carbonáticas do topo da Formação Gandarela, pelo método $\mathrm{Pb} / \mathrm{Pb}$, obtendo a idade de $2420 \pm 5 \mathrm{Ma}$. Para o Grupo Sabará, sequência superior do Supergrupo Minas, os dados de U-Pb de zircão detrítico indicam uma idade mínima de deposição de $2125 \pm 4 \mathrm{Ma}$, e datações de grãos de monazita, em pegmatitos que cortam o embasamento e o Grupo Sabará, indicam uma idade mínima de deposição de $2030 \mathrm{Ma}$ (Machado et al., 1992). Deste modo, os dados geocronológicos para a base do Supergrupo Minas apontam um intervalo de sedimentação na bacia entre 2,6 a 2,4 Ga. Com base em uma estimativa da taxa de sedimentação da ordem de $50 \mathrm{~m} / \mathrm{Ma}$, Renger et al. (1994) propõem que a idade de deposição da Formação Cauê seria de 2520 Ma. Cabral et al. (2012) dataram zircões, pelo método $\mathrm{U} / \mathrm{Pb}$, de intercalações de origem vulcânica na formação ferrífera do Grupo Itabira e obtiveram a idade de 2,65 Ga, ou seja, consideravelmente mais antiga que os dados geocronológicos anteriores.

\section{RESULTADOS}

Para amostragem destinada a estudos isotópicos, foram selecionadas três amostras de furos de sondagem, sendo duas de xisto (amostras 1 e 2) e uma de quartzito (amostra 3), todas correspondendo à Unidade Lagoa da Prata.

As três amostras analisadas apresentam zircões detríticos angulares a arredondados que variam de 80 a $200 \mu \mathrm{m}$. As imagens de CL mostram que a maioria dos grãos possuem núcleos herdados e bordas com zoneamento típico de origem magmática (Figura 12). Ambos, núcleo herdado e borda, foram analisados. Os núcleos herdados definem 37 populações de idades 2611,9 a 3928,4 Ma. As bordas definem populações mais jovens de idades 2587,9 a 2786,4 Ma.
A

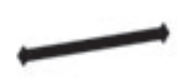

\section{Serra de Bom Sucesso}

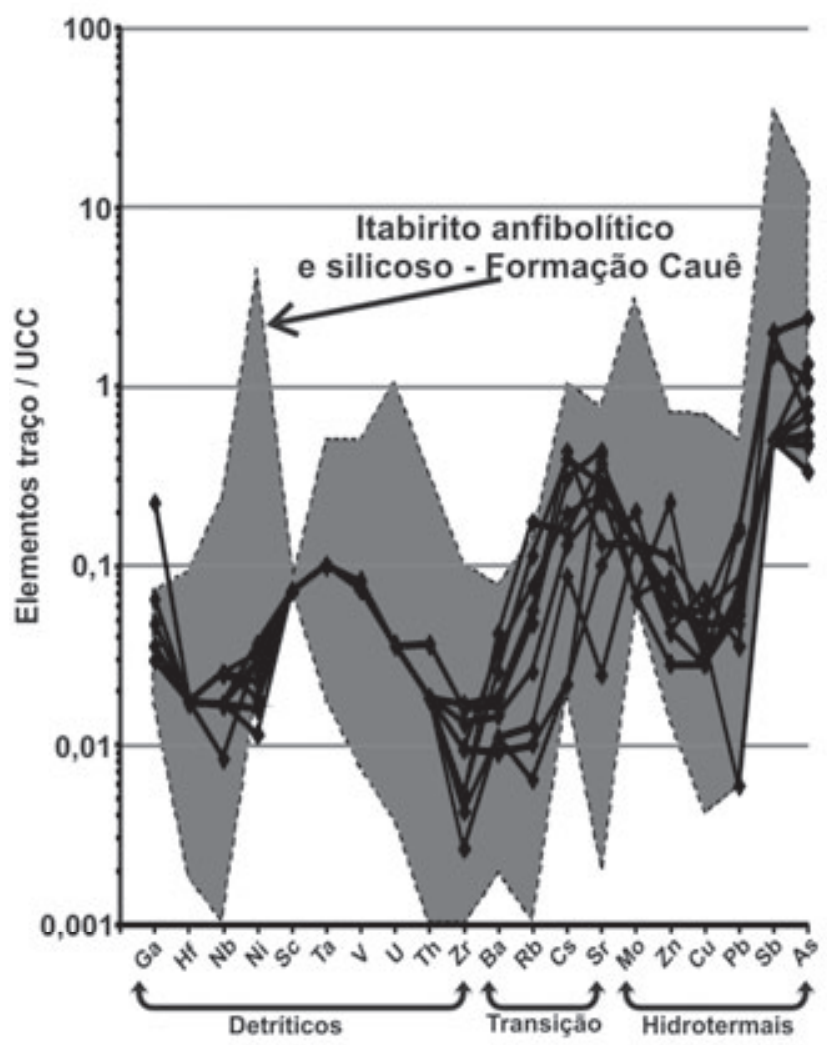

$\mathrm{B}$
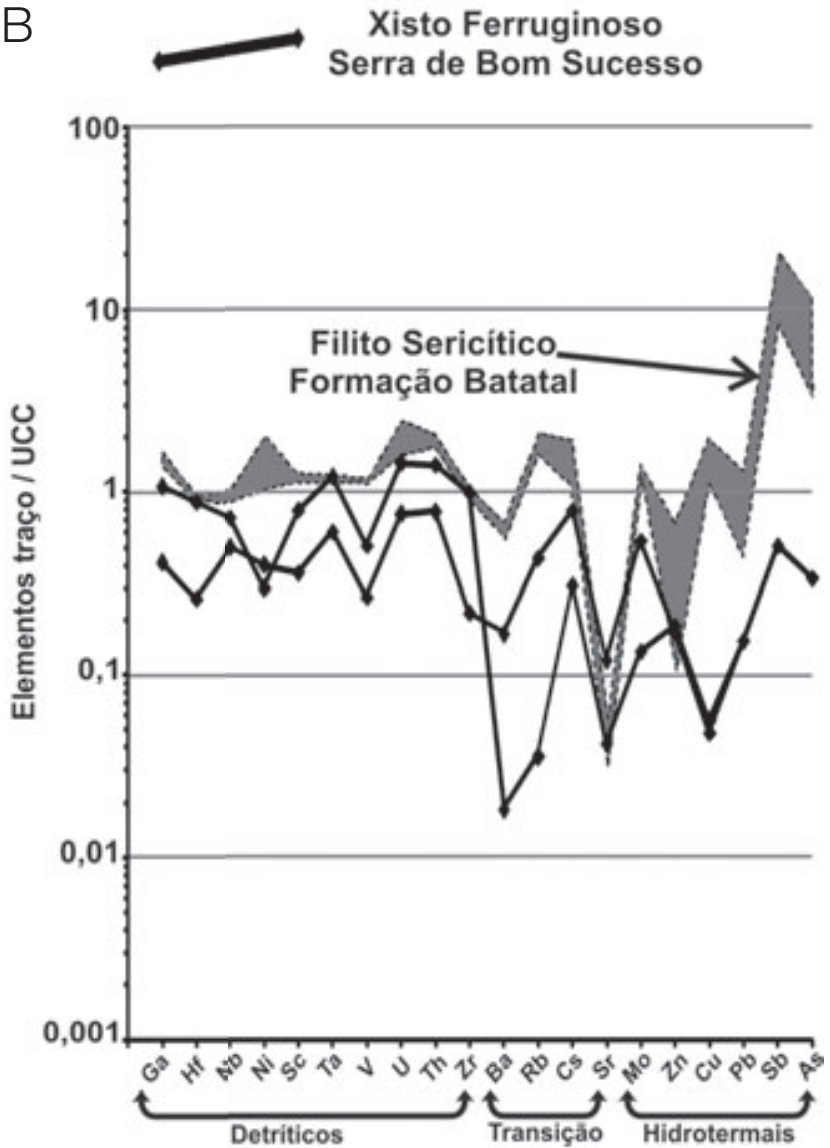

Figura 10. Elementos traço normalizadas ao padrão UCC e discriminados os elementos detríticos, de transição e hidrotermais. (A) amostras de formação ferrífera bandada (FFB) da Serra de Bom Sucesso em comparação com amostras de Itabiritos anfibolíticos e silicosos da Formação Cauê; (B) amostras de xisto ferruginoso da Serra de Bom Sucesso em comparação com amostras de filito sericítico da Formação Batatal. 
Nas duas amostras de xisto, foram obtidas idades de $3451 \pm 7,3$ Ma a $2603 \pm 7,3$ Ma (Figuras $13 \mathrm{~A}$ e $13 \mathrm{~B}$ ) e, em uma amostra de quartzito, idades de zircões de $3323 \pm$ $3 \mathrm{Ma}$ a $2616 \pm 5,7 \mathrm{Ma}$ (Figura 13C). O mais baixo valor encontrado, $2603 \pm 7,3 \mathrm{Ma}$, determina a idade máxima de deposição da unidade basal da Sequência metassedimentar Serra de Bom Sucesso, idade muito próxima à proposta para o início da deposição da Bacia Minas.

\section{DISCUSSÃO}

\section{Idade da Sequência Metassedimentar Bom Sucesso}

Os dados geocronológicos indicam a idade máxima de deposição da Unidade Lagoa da Prata, base da Sequência Metassedimentar Bom Sucesso, em 2,60 Ga, semelhante à idade definida por Machado et al. (1996) para a deposição da Formação Moeda, base do Supergrupo Minas. Possivelmente, não apenas a Sequência Bom Sucesso, mas todas as faixas de metassedimentos similares, alinhadas ao lineamento Jeceaba-Bom Sucesso, representam um prolongamento da Bacia Minas no extremo sudoeste do Quadrilátero Ferrífero.

\section{Arcabouço estrutural}

As macro e microestruturas caracterizadas na Serra de Bom Sucesso são muito semelhantes às estruturas riacianas descritas por diversos autores no Supergrupo Minas (Alkmim e Marshak, 1998; Dorr, 1969; Chemale Jr. et al., 1991, 1994; entre outros). Ambas apresentam o mesmo sistema de dobras e frentes de empurrões com vergência para $\mathrm{NW}$, relacionado à fase colisional que resultou no fechamento da Bacia Minas (Alkmim e Marshak, 1998; Teixeira e Figueiredo, 1991). A vergência para NW
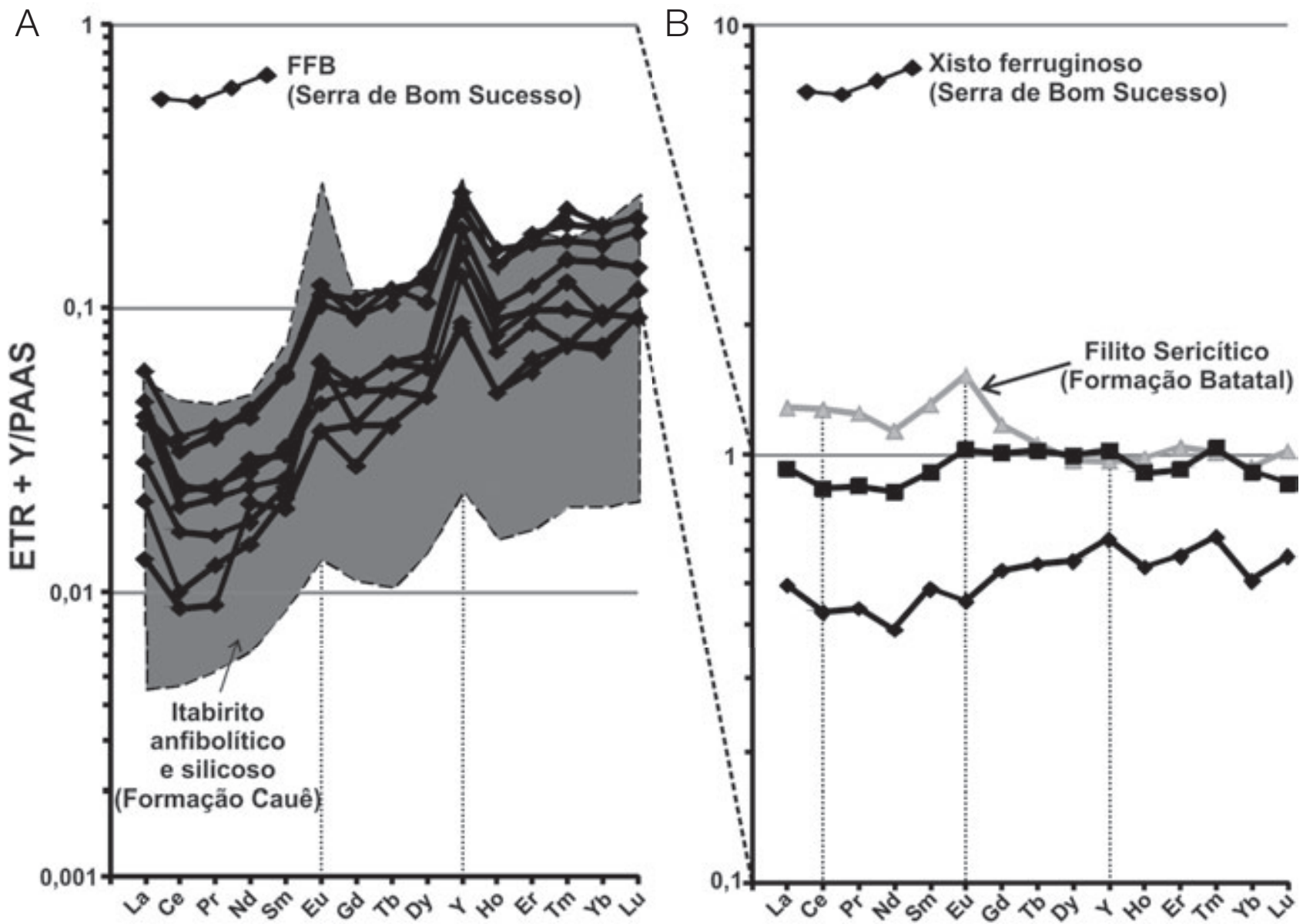

Figura 11. Elementos Terras Raras (ETR) normalizados ao padrão Post-Archean average Australian Shale (PAAS). (A) amostras de formação ferrífera bandada (FFB) da Serra de Bom Sucesso em comparação com amostras de itabiritos anfibolíticos e silicosos da Formação Cauê; (B) xisto ferruginoso da Serra de Bom Sucesso em comparação com filito sericítico da Formação Batatal. 


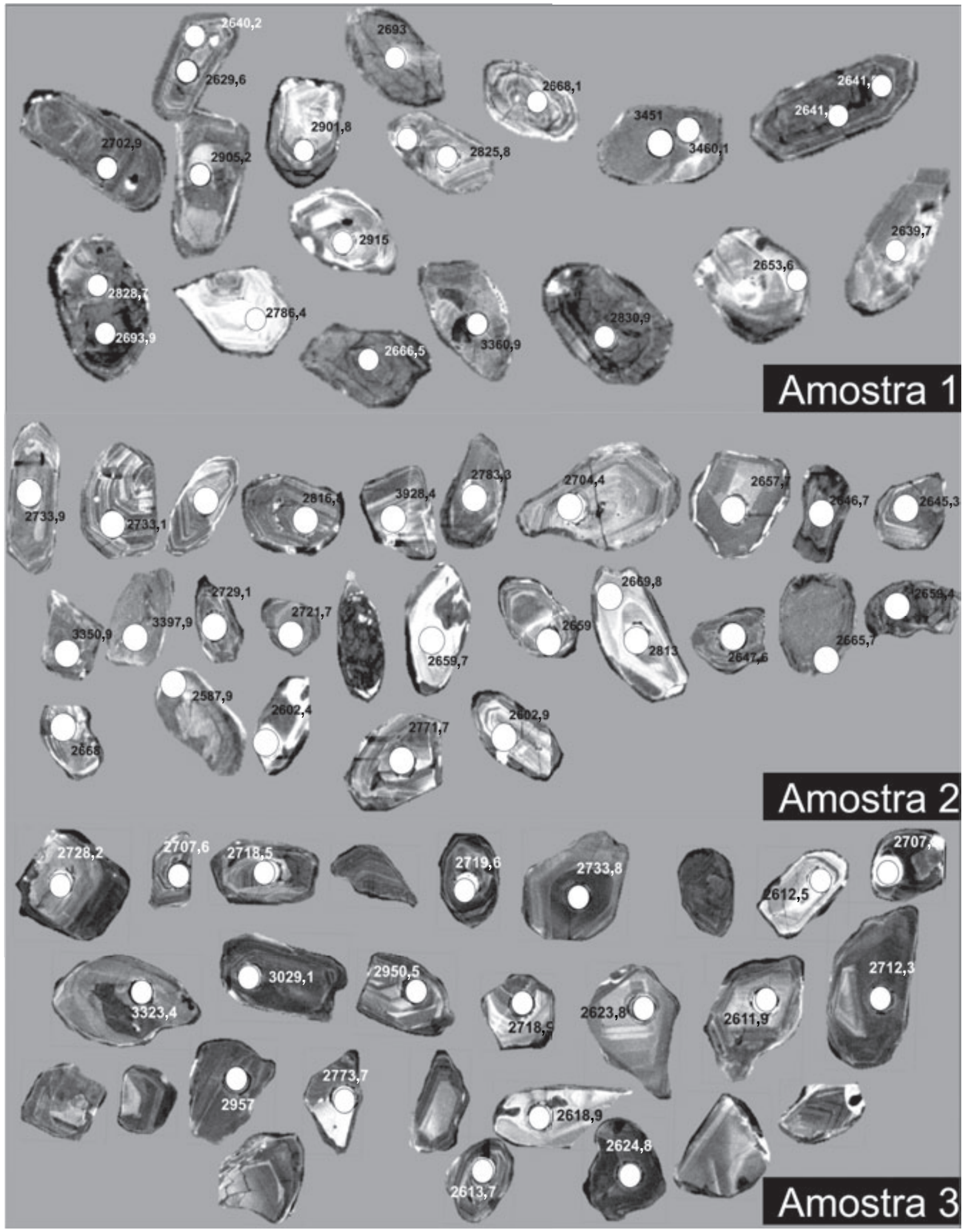

Figura 12. Imagens de catodoluminescência de grãos de zircão e respectivos spots analisados (indicados com círculo e numerados). O tamanho do círculo é de $30 \mu \mathrm{m}$. 

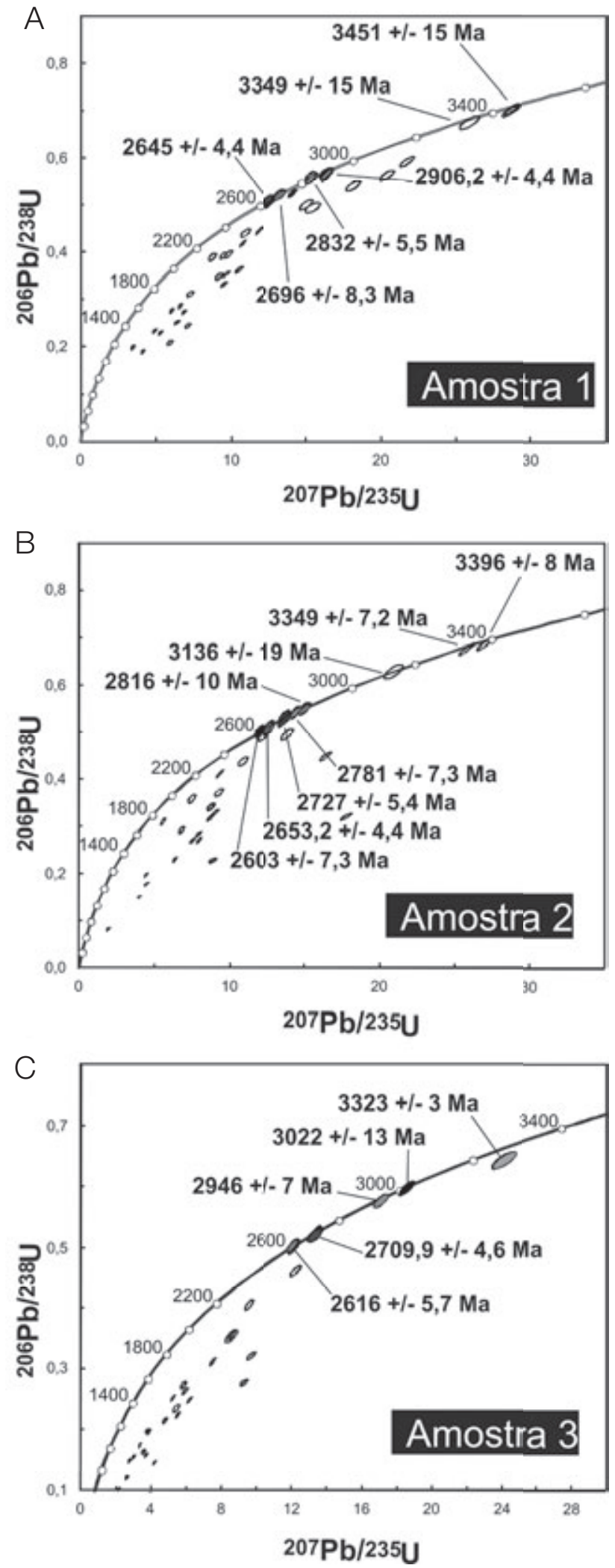

Figura 13. Diagrama de concórdias das amostras (1, 2 e 3) da Unidade Lagoa da Prata na Serra de Bom Sucesso. das dobras $\left(\mathrm{D}_{1}\right.$ e $\left.\mathrm{D}_{2}\right)$, eixos $\left(\mathrm{D}_{2}\right)$ de direção NE-SW com caimento sub-horizontal e foliação planoaxial $\left(\mathrm{S}_{1}\right)$ de direção NE-SW e mergulho para SE, pressupõem que a movimentação tectônica ocorreu de SE para NW. A lineação de estiramento caindo para NE sugere movimento reverso, com componente direcional para SW. Deste modo, é possível que inicialmente houvesse um movimento reverso em rampa frontal, com transporte de massa de SE para NW, associado à foliação principal $\left(\mathrm{S}_{1}\right)$ e ao conjunto de dobras $\left(\mathrm{D}_{1}\right.$ e $\left.\mathrm{D}_{2}\right)$. Posteriormente, as rampas frontais assumiram movimento oblíquo, originando as lineações com caimento para NE.

\section{Metamorfismo, retrometamorfismo e metassomatismo}

No contexto regional, o Cinturão Mineiro apresenta um zonamento metamórfico que varia da fácies xisto verde a granada-anfibolito (Dorr, 1964; Herz, 1978). As associações minerais observadas na Sequência Metassedimentar Bom Sucesso indicam condições de estabilidade da fácies sillimanita-álcali-feldspato, determinada pela associação hedenbergita + microclina \pm enstatita-ferrossilita \pm ferro-augita, e posterior retrometamorfismo em fácies granada-anfibolito, definido por cummingtonita-grunerita \pm tremolita-ferro-actinolita \pm biotita \pm almandina \pm ferro-hornblenda. Minerais aluminosos e alcalinos, como granada almandina, ferro-hornblenda, biotita, ferro-augita e microclina, não são observados nos Itabiritos da Formação Cauê (Supergrupo Minas), como demonstrado na Tabela 3, nem são usuais na maior parte das formações ferríferas bandadas, caracterizando, deste modo, situações

Tabela 3. Mineralogia principal caracterizada na formação ferrífera bandada (FFB) da Serra de Bom Sucesso em comparação com mineralogia principal típica dos Itabiritos da Formação Cauê, Supergrupo Minas (Rosière e Chemale Jr., 1993).

\begin{tabular}{|c|c|c|}
\hline & Serra de Bom Sucesso & Itabirito - SG. Minas \\
\hline \multirow{11}{*}{ 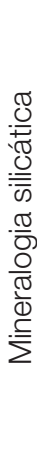 } & Quartzo & Quartzo \\
\hline & Cummingtonita - grunerita & Cummingtonita-grunerita \\
\hline & Tremolita - ferro - actinolita & Tremolita/actinolita \\
\hline & Hedenbergita & \\
\hline & Enstatita - ferrossilita & \\
\hline & Ferro-augita & \\
\hline & Biotita & \\
\hline & Andradita & \\
\hline & Almandina & \\
\hline & Microclina & \\
\hline & Ferro-Hornblenda & \\
\hline
\end{tabular}

Em negrito, estão destacados os minerais com conteúdos em álcalis e/ou alumínio. SG.: Supergrupo. 
particulares, tais como contaminação por sedimentos vulcanogênicos ou metassomatismo alcalino.

Minerais com conteúdo em álcalis e/ou alumínio são identificados tanto nas associações em fácies sillimanita-álcali-feldspato (microclina e ferro-augita; Tabela 4) quanto no retrometamorfismo em fácies granada-anfibolito (biotita, almandina e ferro-hornblenda). As mesmas transformações minerais observadas na FFB, com hedenbergita parcialmente substituída por cristais laminados ou aciculares de cummingtonita-grunerita e tremolita-ferro-actinolita, são observadas no contato com veios de quartzo, carbonato e/ou granatíferos comumente alojados nos planos da foliação principal. Na região do contato com estes veios, também foram identificados anfibólios da série cummingtonita-grunerita, com granulação grossa e textura decussada, indicando metamorfismo termal nessas regiões, diferentemente da textura nematoblástica a granonematoblástica, geralmente observada, nas porções de FFB onde não há presença de veios.

O Granito Tabuões tem contato intrusivo com a Sequência Metassedimentar Bom Sucesso. Próximo ao contato com apófises do granito, os veios têm maior concentração de sulfetos (pirita e/ou pirrotita) e a FFB é composta por ferro-augita, cummingtonita-grunerita, ferro-hornblenda, magnetita, pirita e pirrotita, sendo a ferro-augita parcialmente substituída por cummingtonita-grunerita e ferro-hornblenda. Relacionando o metamorfismo na fácies sillimanita-álcali-feldspato com a mineralogia atípica observada por toda a FFB e também nos contatos com os veios e com as apófises do granito, conclui-se que essa associação mineral é produto de metassomatismo alcalino de contato gerado pela intrusão do Granito Tabuões. A intrusão foi certamente sin-tectônica, com o desenvolvimento de foliação paralela ao contato ígneo $\left(\mathrm{S}_{1}\right)$ igualmente desenvolvida na rocha plutônica e no metassedimento encaixante. As apófises, os veios e a mineralogia alcalina e de alta temperatura encontram-se controlados pela mesma foliação (S S $_{1}$. Teixeira e Martins (1996) definiram a idade do granito como 2,2 $\mathrm{Ga}(\mathrm{Rb}-\mathrm{Sr})$, coincidente com o final da fase de deposição do Grupo Piracicaba e início do fechamento da Bacia Minas (sedimentação do Grupo Sabará) e da Orogênese Transamazônica (Alkmim e Marshak, 1998; Teixeira e Figueiredo, 1991; Endo, 1997).

O retrometamorfismo de fácies granada-anfibolito está relacionado ao metamorfismo regional e possivelmente reflete o reequilíbrio das condições de pressão e temperatura com o resfriamento e cristalização do granito. A associação mineral tremolita, plagioclásio e epidoto, observada

Tabela 4. Tabela de estabilidade de minerais relacionando os minerais diagenéticos, caracterizados por Klein (2005) para formações ferríferas pré-cambrianas, e as transformações minerais observadas na Unidade FFB Bom Sucesso.

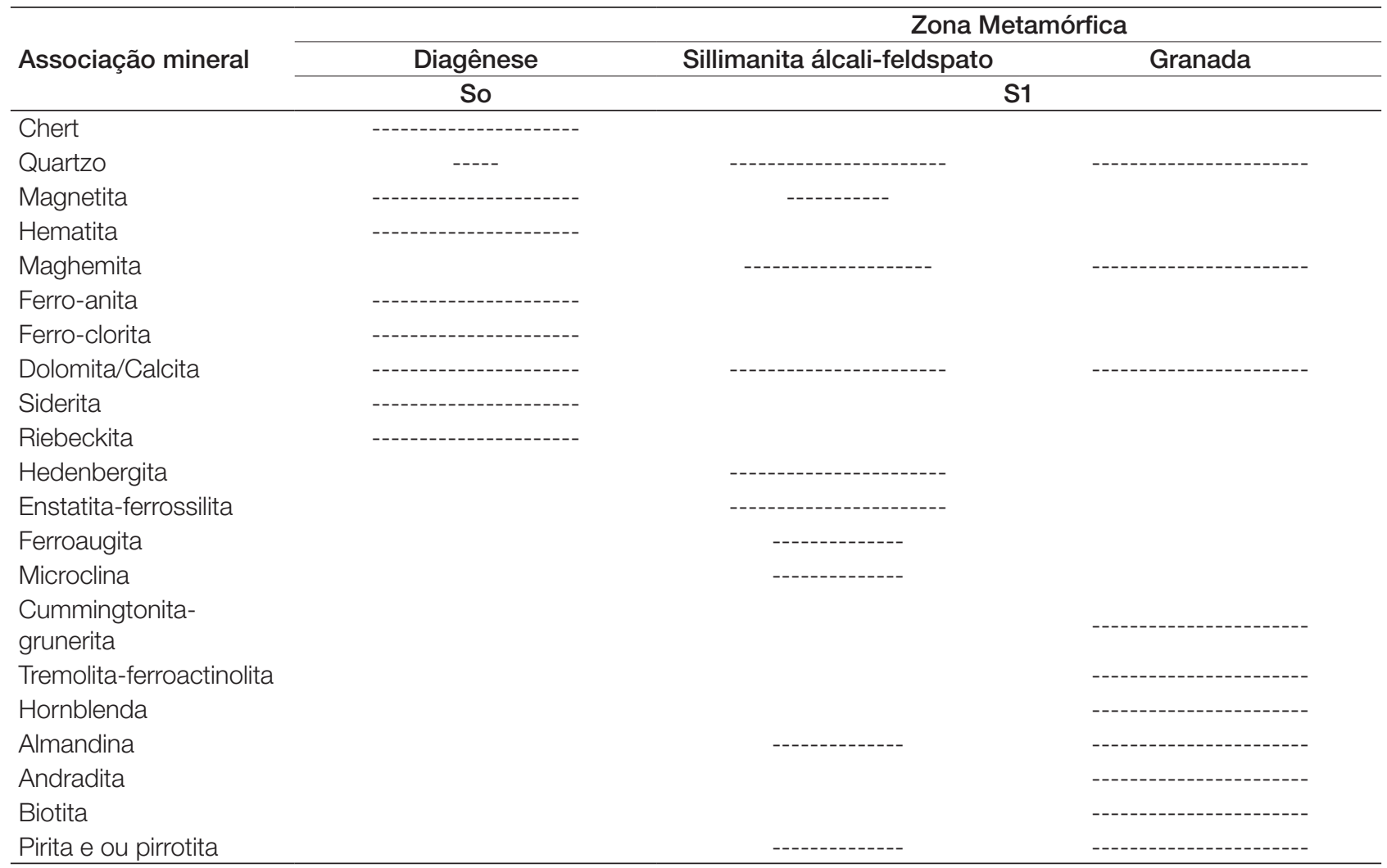


no Greenstone Belt Rio das Mortes, e a mineralogia da FFB Bom Sucesso indicam metamorfismo regional na fácies anfibolito médio e sugerem que o ambiente tectono-metamórfico local corresponde à zona metamórfica da tremolita-antofilita, definida por Pires (1994) no extremo leste do Quadrilátero Ferrífero.

A maghemita requer água ou íons $\mathrm{H}^{+}$para se manter estável (Swaddle e Oltmann, 1980; Waychunas, 1991). A oxidação de magnetita em maghemita ocorre rapidamente se um suficiente número de moléculas de água ou de $\mathrm{H}^{+}$ está presente para preservar a estrutura durante a oxidação; caso contrário, na ausência de água, forma-se hematita (Swaddlle e Oltmann, 1980). A presença de maghemita inclusa nos cristais de hedenbergita sugere que a maghemitização do óxido de ferro na FFB da Serra de Bom Sucesso teve início durante o metamorfismo de contato e provavelmente perdurou durante o retrometamorfismo na fácies granada-anfibolito, já que maghemita também ocorre como cristais elongados segundo a foliação principal $\left(\mathrm{S}_{1}\right)$.

\section{FFB Bom Sucesso e Xisto Ferruginoso}

Com exceção da presença de álcalis, a FFB da Serra de Bom Sucesso é muito similar aos itabiritos da Formação Cauê em relação aos elementos maiores e elementos traço. A concentração de elementos traço de ambas as FFB mostra ainda enriquecimento relativo dos elementos de transição e hidrotermais em relação aos elementos detríticos, sugerindo um mesmo ambiente deposicional com sedimentação distante dos grandes centros hidrotermais exalativos e participação insignificante de componentes clásticos, típicos de outras formações ferríferas bacinais (Tipo Lago Superior).

A assinatura de ETR + Y observada na FFB da Serra de Bom Sucesso são típicas de formações ferríferas arqueanas e paleoproterozoicas, com anomalias positivas de $\mathrm{Eu}, \mathrm{Y}$ e La, enriquecimento relativo de ETR pesados e ausência de anomalia negativa de Ce (e.g. Planavsky et al., 2010). A ausência de anomalia significativa de Ce pressupõe que, durante a precipitação dos óxidos-hidróxidos de $\mathrm{Fe}$, a concentração de Ce e La estava em equilíbrio com a água do mar e não havia uma concentração de oxigênio suficiente para fracionar o Ce(III) no menos solúvel, Ce(IV).

$\mathrm{O}$ xisto ferruginoso do topo da unidade FFB Bom Sucesso é rico em ferro e tem concentração de alumínio muito similar a outras rochas metapelíticas, como o filito sericítico da Formação Batatal aqui usado como termo de comparação. A assinatura de crosta superior, apresentada na concentração de elementos traço, associada à depleção dos elementos de transição e hidrotermais, marca, possivelmente, o aumento gradativo da contribuição de componentes clásticos.

Diagramas triangulares de elementos litófilos, propostos por Bhatia e Crook (1986), e o diagrama binário que relaciona $\mathrm{Th} / \mathrm{Sc}$ e $\mathrm{Zr} / \mathrm{Sc}$, de McLennan et al. (1993), são usados para definir ambientes em sedimentos detríticos associados a sequências vulcanossedimentares, mas podem também indicar possíveis fontes dos sedimentos. Enquanto os elementos maiores geralmente refletem a mineralogia principal e produtos de alteração, os elementos traço retêm a assinatura original das rochas fontes (McClung, 2006). Durante o retrabalhamento e transporte sedimentar, há a concentração de minerais pesados como zircão, monazita, titanita etc. (McLennan, 1988; McLennan et al., 1993). Consequentemente, há o enriquecimento em elementos incompatíveis como Th e Zr. Relacionando a concentração desses elementos com a concentração do elemento compatível, como Sc, é possível indicar possíveis fontes e/ou retrabalhamento sedimentar.

Dentro desse contexto, a Figura 14A demonstra que a FFB da Serra de Bom Sucesso tem maior concentração de Sc do que de Th e Zr, com concentrações próximas aos campos indicados para arcos de ilhas oceânicos, e indica que não houve participação de componentes clásticos crustais durante a sedimentação. $\mathrm{O}$ xisto ferruginoso e filito sericítico mostram concentrações próximas aos campos de margem continental ativa e arco de ilhas continental, indicando possível participação vulcânica na sedimentação. Quando os elementos incompatíveis Th e Zr são comparados com Sc (Figura 14B), a razão $\mathrm{Zr} / \mathrm{Sc}$ forma um excelente indicador de concentração de zircão e, consequentemente, de retrabalhamento sedimentar. Similarmente, a razão $\mathrm{Th} / \mathrm{Sc}$ reflete a concentração de monazita, indicando, deste modo, o grau de fracionamento ígneo da área fonte (McLennan et al., 1993). A FFB da Serra de Bom Sucesso contém razões próximas às das rochas com filiação mantélica; o xisto ferruginoso e filito sericítico apresentam covariação linear positiva, sugerindo retrabalhamento sedimentar de fonte terrígena (McClung, 2006).

Similarmente aos Itabiritos da Formação Cauê, a FFB da Serra de Bom Sucesso não apresenta anomalias negativas de Ce, mas anomalias positivas de La (Figura 15). $\mathrm{O}$ elemento Ce pode ocorrer no estado tetravalente ou trivalente, dependendo do condições redox (McLennam, 1989), e anomalias deste elemento são particularmente interessantes porque podem registrar as condições redox da coluna de água durante o início da diagênese (Holser, 1997). A oxidação de Ce(III) reduz grandemente a solubilidade de Ce, resultando na sua remoção em óxidos e hidróxidos de $\mathrm{Fe}$, matéria orgânica e partículas de argila (Byrne e Sholkovitz, 1996). Em contraste, águas subóxicas e anóxicas não apresentam significantes anomalias negativas de $\mathrm{Ce}$, devido à reduzida dissolução (German et al., 1991; Byrne e Sholkovitz, 1996).

A FFB da Serra de Bom Sucesso contém razões Y/ Ho dentro da faixa de valores apresentados nos itabiritos da Formação Cauê (Figura 16), e o xisto ferruginoso 
possui razões próximas às apresentadas no filito sericítico da Formação Batatal. Ao contrário do Ce, a solubilidade do Y aumenta em ambientes oxidantes (Bolhar et al., 2004), e o Ho é preferencialmente absorvido pelas partículas em suspensão, refletindo em altas razões Y/Ho (> 44) na água
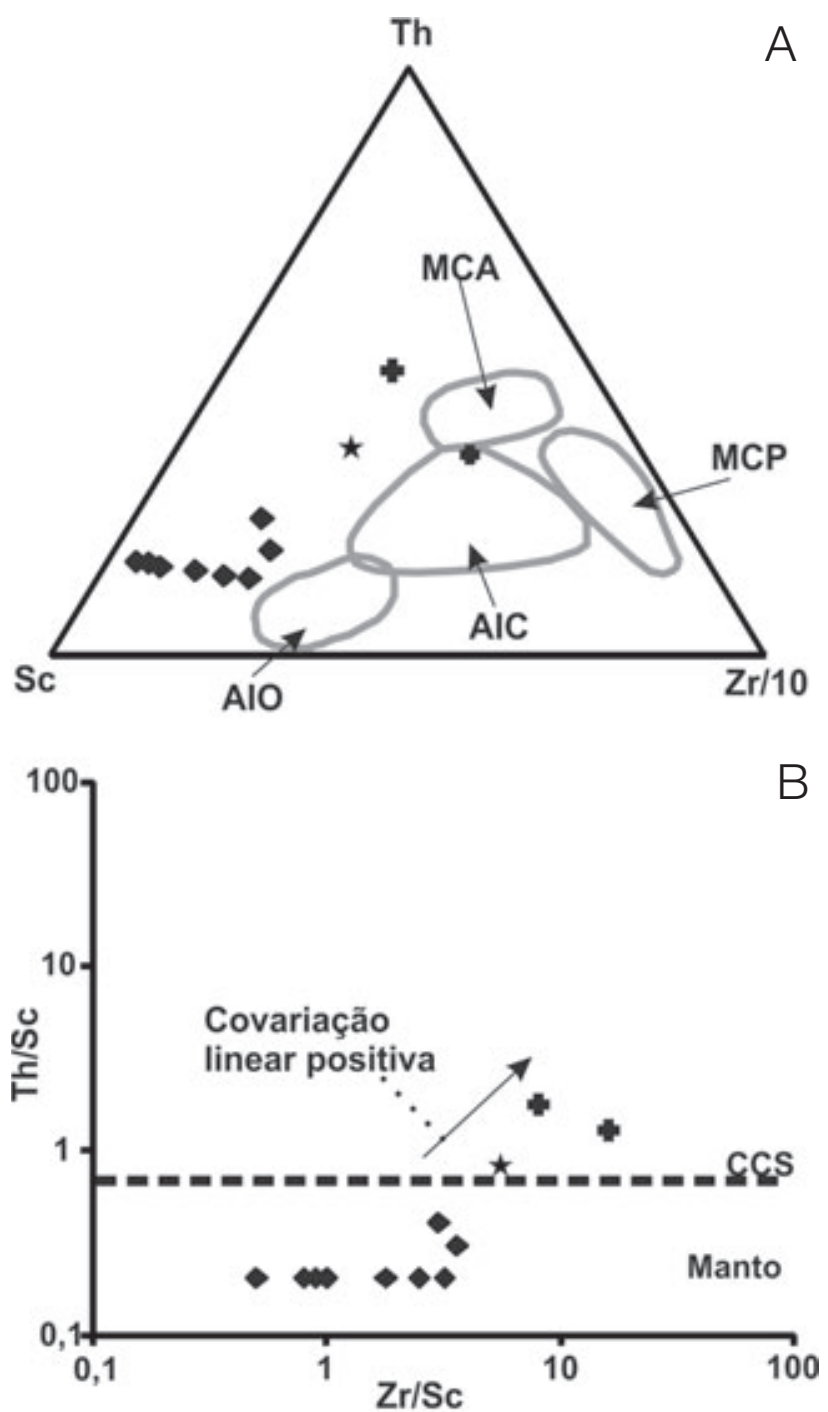

\section{Legenda}

- FFB (Serra de Bom Sucesso)

Xisto Ferruginoso (Serra de Bom Sucesso)

Filito Sericítico (Fm. Batatal)

MCA: Margem continental ativa; MCP: Margem continental passiva; AIC: Arco de ilha continental; AIO: Arco de ilha oceânico; CCS: Crosta continental superior. FFB: formação ferrífera bandada; Fm.: Formação.

Figura 14. Diagrama triangular $\mathrm{A}$ (Th versus Sc versus Zr/10 - Bhatia e Crook, 1986) e diagrama binário B (Th/Sc versus $\mathrm{Zr} / \mathrm{Sc}$ - McLennan et al., 1993). do mar e valores próximos a 26 nos sedimentos argilosos (e.g. PAAS). Consequentemente, a sedimentação química, em equilíbrio com as concentrações de ETR $+\mathrm{Y}$ da água do mar, gerariam rochas, como a FFB, com altas razões $\mathrm{Y} /$ Ho. Em ambientes anóxicos e subóxicos, a solubilidade de Ho aumenta, não sendo incorporado pelas partículas em suspensão (Bau et al., 1997) e, deste modo, a razão Y/Ho na FFB diminui. No entanto, segundo Planavsky et al. (2010), em bacias anóxicas e subóxicas do final do Arqueano e início do Paleoproterozoico, a oxidação microbial aumenta a

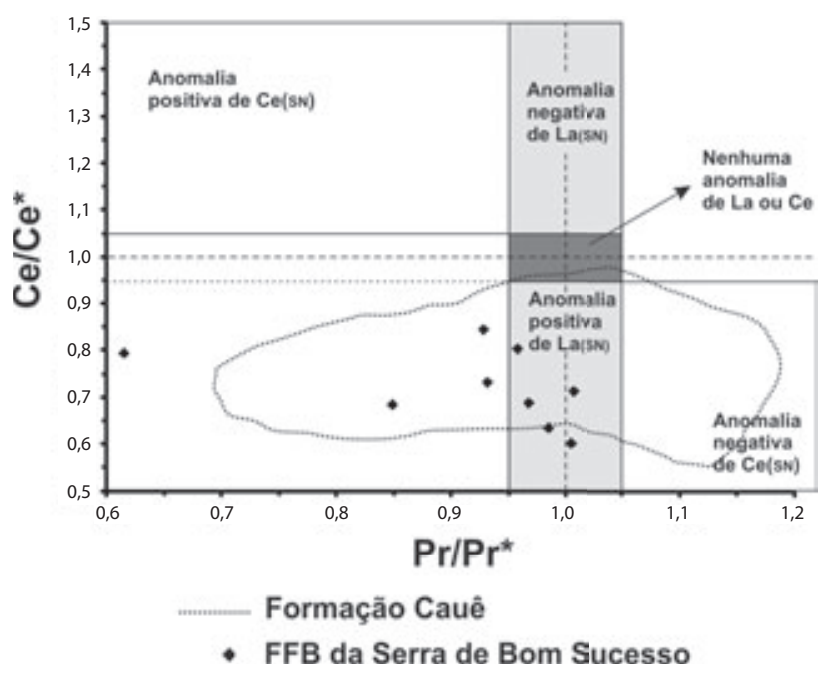

FFB: formação ferrífera bandada.

Figura 15. Diagrama binário de $\mathrm{Ce} / \mathrm{Ce}^{*}{ }_{(\mathrm{PAAS})}$ versus $\mathrm{Pr} /$ $\mathrm{Pr}^{*}{ }_{(\mathrm{PAAS})}$, usado para identificar as anomalias de La e Ce em sedimentos derivados da água do mar (ver Bau e Dulski, 1996).

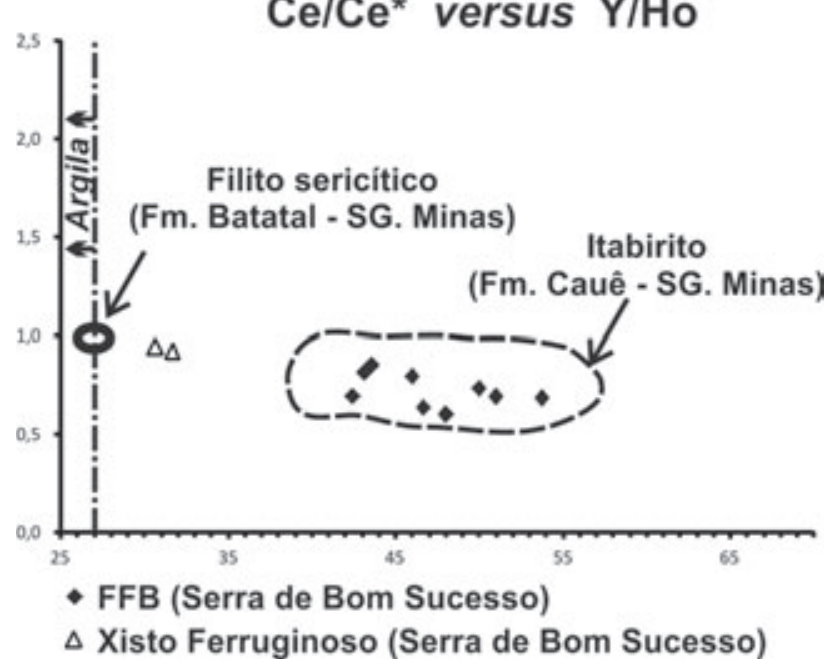

Fm.: Formação; FFB: formação ferrífera bandada. SG.: Supergrupo.

Figura 16. Diagrama binário de $\mathrm{Ce} / \mathrm{Ce}^{*}$ versus $\mathrm{Y} / \mathrm{Ho}$. 
solubilidade do Y, e o Ho é preferencialmente absorvido pelas partículas em suspensão, aumentando os valores da razão em sedimentos químicos, em equilíbrio com a água do mar, como a FFB. No entanto, a falta de marcantes anomalias negativas de Ce pressupõem que a oxidação microbial, que foi responsável pelo aumento da solubilidade de $\mathrm{Y}$, não foi suficiente para fracionar o $\mathrm{Ce}(\mathrm{III})$ em Ce(IV) - menos solúvel -, gerando sedimentos químicos sem depleção de Ce.

$\mathrm{O}$ xisto ferruginoso contém razões $\mathrm{Y} / \mathrm{Ho}$ menores que sedimentos químicos, como a FFB da Serra de Bom Sucesso, e ligeiramente maiores que sedimentos essencialmente clásticos, como o filito sericítico da Formação Batatal, sugerindo que, durante a deposição desse xisto, possivelmente houve um incremento na concentração de $Y$ pela participação, mesmo que pequena, de sedimentação química. Possivelmente, a fração química no xisto ferruginoso é representada pelos anfibólios ricos em ferro, como os da série da cummingtonita-grunerita, que, segundo Klein (2005), são produtos da reação de carbonatos ricos em ferro (dolomita ferroana e siderita) e quartzo.

Uma amostra do xisto ferruginoso contém assinatura de ETR + Y típica de pelitos (e.g. PAAS), e outra amostra apresenta ligeira depleção de ETR $+\mathrm{Y}$ e pequena anomalia positiva de Y (ver Figura 11B). A anomalia positiva de Y confirma participação de sedimentação química nesse litotipo. O Xisto Ferruginoso contém maior concentração relativa de ETR do que a FFB da Serra de Bom Sucesso e não apresenta anomalia de Eu. Pressupõe-se que a participação de sedimentos pelíticos durante a sedimentação teria obliterado a anomalia positiva de Eu, presente nas partículas de óxido de ferro, e aumentado a proporção relativa dos ETR.

\section{Relação estratigráfica entre a Sequência Metassedimentar Bom Sucesso e o Supergrupo Minas}

A relação de topo e base do empilhamento litológico da Sequência Metassedimentar Bom Sucesso também não pode ser diretamente estabelecida, devido à intensidade de deformação sofrida por todas as unidades e consequente falta de estruturas sedimentares e indicadores geoptais. A ausência de unidades superiores em Bom Sucesso não permite a definição de uma sequência de sedimentação nem sua correlação direta com as diferentes formações do Grupo Piracicaba. Entretanto, o xisto carbonático e grafitoso da Unidade Lagoa da Prata, base da Sequência Metassedimentar Bom Sucesso, pode ser correlato dos filitos que marcam o limite superior do Grupo Caraça, estabelecido por Renger et al. (1994). A unidade FFB Bom Sucesso é predominantemente anfibolítica e pode ser correlacionada com a Formação Cauê, sendo o anfibólio produto de metamorfismo com a participação de componentes carbonáticos.
O xisto ferruginoso marca a transição de sedimentação química para um ciclo de sedimentação detrítica, correspondente à Formação Cercadinho, que é produto de erosão e retrabalhamento das formações ferríferas bandadas da Formação Cauê e marca o remodelamento da Bacia Minas (Dorr, 1969; Renger et al., 1994). A Formação Cercadinho é constituída por arenitos e conglomerados ferruginosos com seixos e grãos de formação ferrífera.

A impossibilidade de reconhecer estruturas sedimentares impede a caracterização inequívoca do sedimento que dá origem ao xisto ferruginoso, assim como a definição do ambiente de sedimentação. A assinatura geoquímica, particularmente de ETR, entretanto, permite reconhecer a participação de sedimentos químicos e pelíticos finos. A ausência de sedimentos psamíticos e espessas camadas de carbonatos estromatolíticos sugere ambiente plataformal profundo. A Formação Cercadinho caracterizaria, então, fácies sedimentar proximal, enquanto os metapelitos ferruginosos (xisto ferruginoso), no topo da unidade FFB Bom Sucesso, equivaleriam a uma fácies distal (Figura 17).

A FFB da Serra de Bom Sucesso tem, tanto no topo quanto na base, pacotes metassedimentares que denotam deposição de grande volume de sedimentos pelíticos. Da mesma forma, apenas intercalações métricas de dolomito ferruginoso bandado estão presentes, sem correlação com os dolomitos maciços da Formação Gandarela do Grupo Itabira. Tal configuração sugere que toda a Sequência Metassedimentar do Bom Sucesso seja caracterizada como uma sequência sedimentar de mar profundo. As unidades xistosas e intercalações carbonáticas encontradas podem representar níveis pelíticos e dolomicríticos associados a correntes de turbidez, constituindo um conjunto depositado próximo ao pacote vulcanossedimentar do Greenstone Belt Rio das Mortes, o qual, sugere-se ainda, representaria o centro vulcânico e área de proveniência das exalações hidrotermais, fonte do Fe das formações ferríferas. Esta hipótese, apesar de atrativa, necessita ainda de comprovação por meio de estudos estratigráficos e geoquímicos/isotópicos sistemáticos ao longo de todo o lineamento Jeceaba-Bom Sucesso.

Outra possibilidade para justificar o elevado teor de ferro do xisto ferruginoso seria o seu enriquecimento pela ação de fluidos hidrotermais, possivelmente durante a intrusão do Granito Tabuões, enriquecendo as unidades periféricas à $\mathrm{FFB}$, por reações metassomáticas. Os veios de carbonato contêm maghemita euédrica a subédrica disseminada, confirmando que realmente houve remobilização de ferro. No entanto, as concentrações de elementos maiores, traços e terras raras, observadas no xisto ferruginoso, não registram anomalia de nenhum outro elemento, permitindo, deste modo, indicar ou sugerir tal enriquecimento em ferro. 


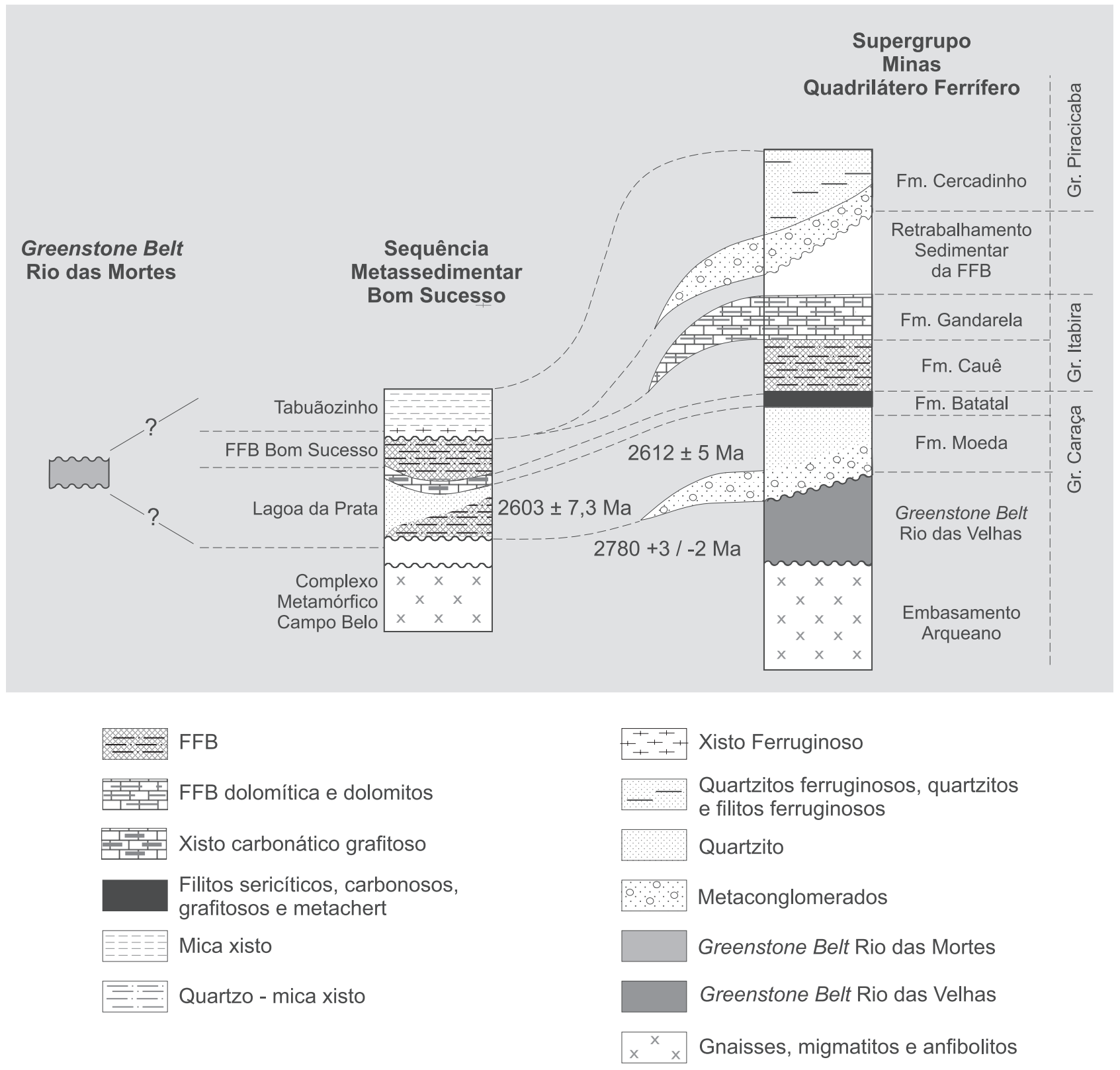

Fm.: Formação. FFB: formação ferrífera bandada.

Figura 17. Coluna lito-estratigráfica esquemática da Sequência Metassedimentar Bom Sucesso em comparação com o Supergrupo Minas no Quadrilátero Ferrífero (Rosière et al., 2008, modificado de Dorr, 1969).

\section{CONCLUSÃO}

A Sequência Metassedimentar Bom Sucesso compõe um empilhamento estratigráfico normal, depositado em ambiente bacinal provavelmente de mar profundo, com o predomínio de rochas metapelíticas, e representa uma extensão da Bacia Minas no extremo sudoeste do Quadrilátero Ferrífero. Durante a orogênese Transamazônica, as rochas sofreram metamorfismo de contato na fácies sillimanita-álcali-feldspato, associado a metassomatismo alcalino e originado pela intrusão sin-tectônica do Granito Tabuões. Essas transformações metamórficas/metassomáticas geraram, na FFB, associações minerais com maior concentração de metais alcalinos do que comumente é observado nos itabiritos da Formação Cauê e em outras FFB do tipo Lago Superior. A mineralogia foi modificada 
ao longo da orogênese e substituída parcialmente por uma associação de temperatura mais baixa, equilibrando-se na fácies anfibolito, com a geração de formação ferrífera de composição maghemítica-hematítica. A estruturação tectônica apresenta os mesmos elementos encontrados na borda setentrional do Quadrilátero Ferrífero, embora tenha se desenvolvido com maior intensidade, de modo a obliterar parcial a totalmente as características originais das rochas que compõem a sequência.

A Unidade Lagoa da Prata, base da Sequência Metassedimentar Bom Sucesso, é correlata da Formação Batatal, Grupo Caraça, e tem idade máxima de deposição determinada em 2,60 Ga. A Unidade FFB Bom Sucesso apresenta características geoquímicas de elementos traço típicas de outras formações ferríferas no mundo inteiro, apresentando anomalias positivas de $\mathrm{Eu}, \mathrm{Y}$ e La, enriquecimento relativo de ETR pesados e ausência de anomalia negativa de $\mathrm{Ce}$, de forma análoga aos itabiritos da Formação Cauê, Grupo Itabira. O xisto ferruginoso encontrado no topo da formação ferrífera, por outro lado, apresenta contribuição predominantemente detrítica e, juntamente com a Unidade Tabuãozinho, pode corresponder ao pacote metassedimentar do Grupo Piracicaba.

\section{AGRADECIMENTOS}

Os autores agradecem à empresa MMX, mineração do Grupo EBX, pelo apoio financeiro e acesso a sua jazida e aos furos de sondagem. À Prof ${ }^{a}$ Márcia Ernesto, do Departamento de Geofísica, Instituto de Astronomia, Geofísica e Ciência Atmosféricas da Universidade de São Paulo (IAG/USP), pelas análises termomagnéticas realizadas. À Fundação de Amparo à Pesquisa do Estado de São Paulo (FAPESP), que auxiliou a obtenção dos dados geocronológicos, e à Fundação de Amparo à Pesquisa do Estado de Minas Gerais (FAPEMIG), projeto CRA-RDP-00067-10, pelo apoio às análises geocronológicas. Os trabalhos receberam ainda apoio dos projetos Magnetititos (CNPq Proc. $n^{\circ}$ 472602/2009-8) e FAPEMIG/ FAPESP/FAPESPA/VALE S.A. Proc. N ${ }^{\circ}$ CRA - RDP00067-10. O autor MENVN agradece particularmente à FAPEMIG e ao Conselho Nacional de Desenvolvimento Científico e Tecnológico (CNPq) pelas bolsas de estudos.

\section{REFERÊNCIAS}

ALKMIM, F. F.; NEVES, B. B. B.; ALVES, J. A. C. Arcabouço tectônico do Cráton do São Francisco - Uma revisão. In: DOMINGUEZ, J. M. L.; MISI, A. O Cráton do São Francisco. Salvador: SBG-NBA/SE, SGM, CNPq, 1993. p. 45-62.
ALKMIM, F. F.; MARSHAK, S. Transamazonian Orogeny in the Southern São Francisco Craton Region, Minas Gerais, Brazil: evidence for Paleoproterozoic collision and collapse in the Quadrilátero Ferrífero. Precambrian Research, v. 90, p. 29-58, 1998.

ALKMIM, F. F. O que faz um cráton? O Cráton do São Francisco e as revelações almeidianas ao delimitá-lo. In: BARTORELLI, A.; CARNEIRO, C. D. R.; BRITO NEVES, B. B. Geologia do continente sul-americano: evolução da obra de Fernando Flávio Marques de Almeida. São Paulo: Beca, 2004. p. 18-35.

ALMEIDA, F. F. M. O Cráton do São Francisco. Revista Brasileira de Geociências, v. 7, p. 349-364, 1977.

BABINSKI, M.; CHEMALE JR., F.; VAN SCHMUS, W. R. Geocronologia $\mathrm{Pb} / \mathrm{Pb}$ em rochas carbonáticas do Supergrupo Minas, Quadrilátero Ferrífero, Minas Gerais. In: CONGRESSO BRASILEIRO DE GEOQUIMÍMICA, 3., 1991. São Paulo. Anais... São Paulo: SBGq, v. 1, p. 628-631, 1991.

BABINSKI, M.; CHEMALE JR, F.; VAN SCHMUS W. $\mathrm{R}$. The $\mathrm{Pb} / \mathrm{Pb}$ age of Minas Supergroup carbonate rocks, Quadrilátero Ferrífero, Brazil, and its implications to the correlation with BIFs from South Africa and Australia. Precambrian Research, v. 72, p. 235-245, 1995.

BAU, M.; DULSKI, P. Distribution of yttrium and rareearth elements in the Penge and Kuruman Iron-Formations, Transvaal Supergroup, South Africa. Precambrian Reasearch, v. 79, p. 37-55, 1996.

BAU, M.; MOLLER, P.; DULSKI, P. Yttrium and lanthanides in eastern Mediterranean seawater and their fractionation during redox-cycling. Marine Chemistry, v. 56, p. 123-131, 1997.

BEST, M. G. Igneous and Metamorphic Petrology. Malden: Blackwell Publishing, 2003. 729 p.

BHATIA, M. B.; CROOK, K. A. W. Trace element characteristics of greywackes and tectonic setting discrimination of sedimentary basins. Contributions to Mineralogy and Petrology, v. 92, p. 181-193, 1986.

BOLHAR, R.; KAMBER, B. S.; MOORBATH, S.; FEDO, C. M.; WHITEHOUSE, M. J. Characterisation of early Archaean chemical sediments by trace element signatures. Earth Planet. Sci., v. 222, p. 43-60, 2004.

BUCHER, K.; GRAPES, R. Petrogenesis of metamorphic rocks. $8^{\text {th }}$ ed. Berlin: Springer-Verlag, 2011. $441 \mathrm{p}$. 
BUICK, I. S.; LANA, C.; GREGORY, C. A. LA-ICP-MS and SHRIMP U/Pb age constraint on the timing of REE mineralisation associated with bushveld granites. South African Journal of Geology, v. 114, p. 1-14, 2011.

BYRNE, R.; SHOLKOVITZ, E. Marine chemistry and geochemistry of the lanthanides. In: GSCHNEIDER JR., K. A.; EYRING, L. Handbook on the Physics and Chemistry of the Rare Earths. Amsterdam: Elsevier, 1996. p. 497-593.

CABRAL, A. R.; ZEH, A.; KOGLIN, N.; SEABRA GOMES JR., A. A.; VIANA, D. J.; LEHMANN, B. Dating the Itabira iron formation, Quadrilátero Ferrífero of Minas Gerais, Brazil, at $2.65 \mathrm{Ga}$ : depositional U-Pb age of zircon from a metavolcanic layer. Precambrian Research, v. 204205, p. 40-45, 2012.

CAMPOS, J. C. S.; CARNEIRO, M. A.; BASEI, M. A. S. $\mathrm{U}-\mathrm{Pb}$ evidence for Late Neoarchean crustal reworking in the southern São Francisco Craton (Minas Gerais, Brazil). Anais da Academia Brasileira de Ciências, v. 75, p. 497-511, 2003.

CHEMALE JR., F.; ROSIÈRE, C. A.; ENDO, I. Evolução Tectônica do Quadrilátero Ferrífero, Minas Gerais um modelo. Pesquisas da Universidade Federal do Rio Grande do Sul, v. 18, p. 104-127, 1991.

CHEMALE JR., F.; ROSIÈRE, C. A.; ENDO, I. Evolução tectônica do Quadrilátero Ferrífero, Minas Gerais: um modelo. Pesquisas da Universidade Federal do Rio Grande do Sul, v. 18, p. 104-127, 1992.

CHEMALE JR., F.; ROSIÈRE, C. A.; ENDO, I. The tectonic evolution of the Quadrilátero Ferrífero, Minas Gerais, Brazil. Precambrian Research, v. 65, p. 25-54, 1994.

DEER, W. A.; HOWIE, R. A.; ZUSSMAN, J. An Introduction to the Rock Forming Minerals. $2^{\text {nd }}$ ed. London: Longman, 1992. 696 p.

DORR, J. N. Supergene iron ores of Minas Gerais, Brazil. In: DORR II, J. V. N. Physiographic, stratigraphic and structural development of the Quadrilátero Ferrífero, Minas Gerais. Professional Paper, USGS, 641-A. Washington. 1969. 110p.

DORR II, J. V. N. Physiographic, stratigraphic and structural development of the Quadrilátero Ferrífero, Minas Gerais. Professional Paper, USGS, 641-A. Washington, 1969. 110p.
DUNLOP, D. J.; ÖZDEMIR, Ö. Rock Magnetism: Fundamentals and Frontiers. London; Cambridge: Cambridge University Press, 1997. 573 p.

ENDO, I. Regimes tectônicos do Arqueano e Proterozóico no interior da placa Sanfranciscana: Quadrilátero Ferrífero e áreas adjacentes, Minas Gerais. 1997. 243 p. Tese (Doutorado) - Instituto de Geociências, Universidade de São Paulo, São Paulo.

GEHRING, A. U.; FISCHER, H.; LOUVEL, M.; KUNZE, K.; WEIDLER, P. G. High temperature stability of natural maghemite: a magnetic and spectroscopic study. Geophysical Journal International, v. 179, p. 1361-1371, 2009.

GERMAN, C. R.; HOLLIDAY, B. P.; ELDERFIELD, H. Redox cycling of rare earth elements in the suboxic zone of the Black Sea. Geochimica et Cosmochimica Acta, v. 55, p. 3553-3558, 1991.

HARTMANN, L. A.; ENDO, I.; SUITA, M. T. F.; SANTOS, J. O. S.; FRANTZ, J. C.; CARNEIRO, M. A.; MCNAUGHTON, N. J.; BARLEY, M. E. Provenance and age delimitation of Quadrilátero Ferrífero sandstones based on zircon $\mathrm{U} \mathrm{Pb}$ isotopes. Journal of South American Earth Sciences, v. 20, p. 273-285, 2006.

HERZ, N. Metamorphic rocks of the Quadrilátero Ferrífero, Minas Gerais, Brazil. Profissional Paper, USGS, 641-C, 1978. $78 \mathrm{p}$.

HOLSER, W.T. Geochemical events documented in inorganic carbon isotopes. Palaeogeography, Palaeoclimatology, Palaeoecology, v. 132, p. 173-182, 1997.

KLEIN, C. Diagenesis and metamorphism of Precambrian iron-formations. In: KLEIN, C. Some Precambrian banded iron-formations (BIFs) from around the world: Their age, geologic setting, mineralogy, metamorphism, geochemistry, and origin. American Mineralogist, v. 90, p. 1473-1499, 2005.

KLEIN, C. Some Precambrian banded iron-formations (BIFs) from around the world: Their age, geologic setting, mineralogy, metamorphism, geochemistry, and origin. American Mineralogist, v. 90, p. 1473- 1499, 2005.

LANA, C.; BUICK, I.; STEVENS, G.; ROSSOUW, R.; DE WET, W. 3230-3200 Ma post-orogenic extension and mid-crustal magmatism along the southeastern margin of the Barberton Greenstone Belt, South Africa. Journal of Structural Geology, v. 33, p. 844-858, 2011. 
MACHADO, N.; NOCE, C. M.; LADEIRA, E. A.; BELO DE OLIVEIRA, O. A. U-Pb geochronology of Archean magmatism and Proterozoic metamorphism in the Quadrilátero Ferrífero, southern São Francisco craton, Brazil. Geological Society of America Bulletim, v. 104, p. 1221-1227, 1992.

MACHADO, N.; SCHRANK, A.; NOCE, C. M.; GAUTHIER, G. Ages of detritcal zircon from ArcheanPaleoproterozoic sequences: Implications for Greenstone Belt setting and evolution of a Transamazoniam foreland basin in Quadrilátero Ferrífero, southeast Brazil. Earth and Planet Science Letters, v. 141, p. 259-276, 1996.

MACHADO FILHO, L.; RIBEIRO, M. W.; GONZALEZ, S. R.; SCHENINI, C. A.; SANTOS, A. N.; PALMEIRA, R. C. B.; TEIXEIRA, W.; CASTRO, H. E. F. Geologia das Folhas 23/24 Rio de Janeiro e Vitória, 1983. In: OLIVEIRA, A. H.; CARNEIRO, M. A. Campo Belo Metamorphic Complex: evolution of an Archean sialic crust of the Southern São Francisco Craton in Minas Gerais (Brazil). Anais da Academia Brasileira de Ciências, v. 73, n. 3, p. 397-415, 2001.

MARSHAK, S.; ALKMIM, F. F.; EVANGELISTA, H. J. Proterozoic crustal extension and the generation of dome and keel structure in an granite-greenstone terrane. Nature, v. 357, p. 491-493, 1992.

MCCLUNG, C. R. Basin analysis of the Bushmanland Group, Namaqualand Metamorphic Complex of the Northern Cape Province, South Africa. 2006. Tese (Doutorado) - University of Johannesburg, South Africa.

MCLENNAN, S. M. Recycling of the Continental Crust. Pure and Applied Geophysics, v. 128, n. 3-4, p. 683-724, 1988.

MCLENNAN, S. M. Rare earth elements in sedimentary rocks: influence of provenance and sedimentary processes. In: LIPIN, B. R.; MCKAY, G. A. (editors). Geochemistry and Mineralogy of Rare Earth Elements, Reviews in Mineralogy, v. 21. 1989. p. 169-200.

MCLENNAN, S. M.; MCCULLOCH, M. T.; TAYLOR, S. R.; MAYNARD, J. B. Effects of sedimentary sorting on neodymium isotopes in deep-sea turbidites. Nature, v. 337, p. 547-549, 1989.

MCLENNAN, S. M.; HEMMING, S.; MCDANIEL, D. K.; HANSON, G. N. Geochemical approaches to sedimentation, provenance, and tectonics. Processes Controlling the Composition of Clastic Sediments. Geological Society of America, Special Paper, v. 284, p. 21-40, 1993.
NOCE, C. M.; MACHADO, N.; TEIXEIRA, W. $\mathrm{U}-\mathrm{Pb}$ geochronology of gneisses and granitoids in the Quadrilátero Ferrífero (southern São Francisco craton): Age constraints for Archean and Paleoproterozoic magmatism and metamorphism. Revista Brasileira de Geociências, v. 28, p. 95-102, 1998.

NOCE, C. M.; TEIXEIRA, W.; QUÉMÉNEUR, J. J. G.; MARTINS, V. T. S.; BOLZACHINI, E. Isotopic signatures of paleoproterozoic granitoids from the southern São Francisco Craton and implications for the evolution of the Transmazonian Orogeny. Journal of South American Earth Sciences, v. 13, p. 225-239, 2000.

OLIVEIRA, A. H. Evolução de um fragmento do Cráton São Francisco Meridional com base em aspectos estruturais, geoquímicos (rocha total) e geocronológicos (Rb-Sr, SmNd, Ar-Ar, U-Pb). 2004. Tese (Doutorado) - Departamento de Geologia da Escola de Minas, Universidade Federal de Ouro Preto, Ouro Preto.

PETER, J. M. Ancient iron formation: their genesis and use in the exploration for stratiform base metal sulphide deposits, with examples from the Bathurst Mining Camp. In: LENTZ, D. R. Geochemistry of Sediments and Sedimentary Rocks: Evolutionary Considerations to Mineral Deposit-Forming Environments. v. 4. Ottawa: Geological Associations of Canada, 2003. p. 145-176.

PLANAVSKY, N.; BEKKER, A.; ROUXEL, O. J.; KAMBER, B.; HOFMANN, A.; KNUDSEN, A.; LYONS, T. W. Rare earth element and yttrium compositions of Archean and Paleoproterozoic Fe formations revisited: New perspectives on the significance and mechanisms of deposition. Geochimica et Cosmochimica Acta, v. 74, n. 22, p. 6387-6405, 2010.

PIRES, F. R. M. Textural and mineralogical variations during metamorphism of the Proterozoic Itabira Iron Formation in the Quadrilátero Ferrífero, Minas Gerais, Brazil. Anais Academia Brasileira de Ciências, v. 67, p. 77-105, 1995.

QUÉMÉNEUR, J. J. G.; RIBEIRO, A.; TROUW, R. A. J.; PACIULLO, F. V. P.; HEILBRON, M. Geologia da folha Lavras 1: 100.000. In: Soares, A. C. P. (Org.). Projeto Sul de Minas. Belo Horizonte: CODEMIG, 2003. p. 259-316

RENGER, F. E.; NOCE, C. M.; ROMANO, A. W.; MACHADO, N. Evolução sedimentar do Supergerupo Minas: 500 Ma de registro geológico no Quadrilátero Ferrífero, Minas Gerais. Geonomos, v. 2, n. 1, p. 1-11, 1994. 
ROMANO, R.; LANA, C.; ALKMIM, F. F.; STEVENS, G. Stabilisation of the Southern São Francisco Craton through a long lived period of potassic magmatism. Precambrian Research, v. 112, 2012. (no prelo)

ROSIÈRE, C. A.; CHEMALE JR., F. Um modelo para a evolução microestrutural dos minerios de ferro do Quadrilátero Ferrífero. Parte I - estruturas e recristalização. Geonomos, v. 1, n. 1, p. 65-84, 1993.

ROSIÈRE, C. A.; SPIER, C. A.; RIOS, F. J.; SUCKAU, V. E. The itabirite from the Quadrilátero Ferrífero and related high-grade ores: an overview. Economic Geology, v. 15, p. 223-254, 2008.

SPIER, C. A.; OLIVEIRA, S. M. B.; SIAL, A. N.; RIOS, F. J. Geochemistry and genesis of the banded iron formations of the Cauê Formation, Quadrilátero Ferrífero, Minas Gerais, Brazil. Precambrian Research, v. 152, p. 170-206, 2007.

SWADDLE, T. W.; OLTMANN, P. Kinetics of the magnetite-maghemite hematite transformation, with special interest of hydrothermal systems. Canadian Journal of Chemistry, v. 58, p. 1763-1772, 1980.

SLÁMA, J.; KOŠLER, J.; CONDON, D. J.; CROWLEY, J. L.; GERDES, A.; HANCHAR, J. M.; HORSTWOOD, M. S. A.; MORRIS, G. A.; NASDALA, L.; NORBERG, N.; SCHALTEGGER, U.; SCHOENE, B.; TUBRETT, M. N.; WHITEHOUSE, M. J. Plešovice zircon-a new natural reference material for $\mathrm{U}-\mathrm{Pb}$ and $\mathrm{Hf}$ isotopic microanalysis. Chemical Geology, v. 249, p. 1-35, 2008.

TAYLOR, S. R.; MCLENNAN, S. M. The Continental Crust: Its Composition and Evolution. 1985. Oxford: Blackwell, $312 \mathrm{p}$.

TEIXEIRA, W.; FIGUEIREDO, M. C. H. An outline of Early Proterozoic crustal evolution in the São Francisco craton, Brazil: a review. Precambrian Research, v. 53, p. 1-22, 1991.

TEIXEIRA, W.; MARTINS, V. T. Granitos Paleoproterozóicos da Porção Meridional do Cráton São Francisco: Estudos isotópicos de $\mathrm{Sr}$ e Nd. Relatório de Projeto de Pesquisa. São Paulo: USP/FAPESP, 1996. 28 p.

TEIXEIRA, W.; SABATÉ, P.; BARBOSA, J.; NOCE, C. M.; CARNEIRO, M. A. Archean and Paleoproterozoic tectonic evolution of the São Francisco Craton, Brazil. In: CORDANI, U. G.; MILANI, E. J.; THOMAZ FILHO, A.; CAMPOS, D. A. Tectonic Evolution of South America. In: INTERNATIONAL GEOLOGICAL CONGRESS, 31., 2000. Rio de Janeiro. p. 101-137.

WAYCHUNAS, G. A. Crystal chemistry of oxides and oxyhydroxides. Mineralogical Society of America Reviews in Mineralogy, v. 25, p. 11-68, 1991.

YARDLEY, B. W. D. Introdução à Petrologia metamórfica [tradução de Reinhardt Adolfo Fuck]. Brasília: Editora da Universidade de Brasília, 2004. 432 p. 